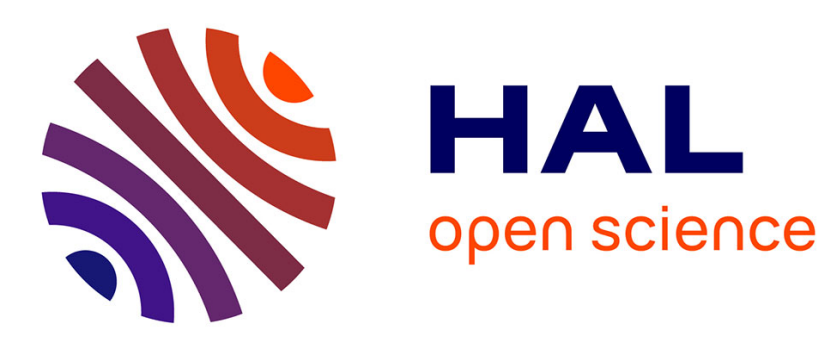

\title{
Global Value Chains and Local Business Environments: Which Factors Really Matter in Developing Countries?
}

Marion Dovis, Chahir Zaki

\section{To cite this version:}

Marion Dovis, Chahir Zaki. Global Value Chains and Local Business Environments: Which Factors Really Matter in Developing Countries?. Review of Industrial Organization, 2020, 57 (2), pp.481-513. 10.1007/s11151-020-09768-w . hal-03123185

\section{HAL Id: hal-03123185 \\ https://hal-amu.archives-ouvertes.fr/hal-03123185}

Submitted on 5 Mar 2021

HAL is a multi-disciplinary open access archive for the deposit and dissemination of scientific research documents, whether they are published or not. The documents may come from teaching and research institutions in France or abroad, or from public or private research centers.
L'archive ouverte pluridisciplinaire HAL, est destinée au dépôt et à la diffusion de documents scientifiques de niveau recherche, publiés ou non, émanant des établissements d'enseignement et de recherche français ou étrangers, des laboratoires publics ou privés. 


\title{
Global Value Chains and Local Business Environments: Which Factors Really Matter in Developing Countries?
}

\author{
Marion Dovis ${ }^{1} \cdot$ Chahir Zaki $^{2}$
}

\begin{abstract}
This study assesses the effect of an economy's business environment on the ability of firms to be part of a global value chain (GVC). With the use of a comprehensive firm-level dataset from the World Bank Enterprise Survey-and with a special focus on the countries of the Middle East and North Africa and East Asia and Pacific regions - the contribution of the paper is threefold: First, it provides a range of measures of the characteristics of firms that would identify a firm as likely to be integrated into a GVC. Second, it examines the association between an array of business environment variables-infrastructure; access to finance; fiscal policy; enforcement of contracts; ease of obtaining permits; extent of the informal sector; trade procedures; and firm and investor security — and the likelihood of a fi rm's being integrated into a GVC. Third, we examine these effects separately for small and large firms and for sectors with high and low tariffs. Our main findings show that, in general, the number of days that are required to pay taxes, the number of procedures that are necessary to register property, and the time to export and to import have a significantly negative association with the likelihood of a firm's integration into a GVC. More heterogeneity is observed at the regional level, at the firm size level, and for sectors with high versus low tariffs.
\end{abstract}

Keywords Global value chains $\cdot$ Firms $\cdot$ Business environment

JEL Classification F12 · F23

Chahir Zaki

chahir.zaki@feps.edu.eg

Marion Dovis

marion.dovis@univ-amu.fr

1 CNRS and EHESS, Aix-Marseille School of Economics, Aix-Marseille University, Marseille, France

2 Faculty of Economics and Political Science, Cairo University and ERF, Giza, Egypt 


\section{Introduction}

Developing countries are increasingly engaged in international production networks that have increased during the past 2 decades. In 2013, 60\% of the international trade was performed through global value chains (GVCs) (UNCTAD 2013). GVCs not only represent the fractionalization process that unbundles supply chains into specific stages of production but also the international scattering of these stages and tasks. In order to reduce costs, most of the required inputs are sourced from other domestic firms or are imported by the producing firm, which creates a production system outside of borders.

This process can take a number of forms for firms: Firms may marginally integrate the production process for one step-or they may engage far more extensively in being vertically integrated. All participants in a GVC-whatever their characteristics-are linked to such activities through the value creation process. Thus, GVCs represent the opportunity for firms to produce and export as a part of a supply chain-depending on their comparative advantages-which is particularly important for developing countries. In this way, integrating into a GVC may facilitate the exports by firms from developing countries. As mentioned by Baldwin (2013), joining supply chains increases the likelihood of exporting.

Yet we know little about the incentives and constraints that influence firms to integrate into a GVC, which makes it hard to identify policy levers to address this issue. The quality of the legal, institutional, financial, and regulatory s ystems plays a crucial role in the development of the performance of firms. Indeed, according to the World Bank (2017), business regulations and their enforcement still vary widely across regions and countries.

The aim of this paper is therefore to highlight the crucial role of the business environment on the integration of firms into GVCs in the case of the Middle East and North African (MENA) countries. Despite heterogeneous performances, the export dynamics of the MENA's countries have been largely unsatisfactory over the past 2 decades. As highlighted by Jaud and Freund (2015), when MENA countries are compared to East Asian and Pacific (EAP) c ountries, the former has export superstars: Their top firms are comparable to those of other countries. However, except for these champions, MENA countries suffer $f$ rom a 1 ack of large and productive firms at the top of the distribution. Significant efforts have been made in terms of trade openness and policy support for firms' transitions; but MENA countries have failed to develop a group of large exporting firms that usually contribute to the success of the export dynamic of a country.

Thus, expanding GVC linkages in the MENA region is crucial for two main reasons: First, MENA countries are much less integrated than are EAP countries in international trade. As integrating into GVCs may facilitate the upgrading and competitiveness of exported goods, it is important to analyze the constraints that are faced by firms in terms of their business e nvironments. S econd, the recent political events in the MENA countries highlighted the urgency of creating jobs and redistributing the benefits of $g$ rowth $t o$ their $p$ opulations. H ence, h elping firms to integrate with GVCs may be relevant to the job challenges in MENA 
countries. Indeed, as highlighted by Brambilla et al. (2012) and by Frias et al. (2012), exporters create more jobs and pay higher wage.

With respect to theory, several papers have showed the association between firms' integration and their performance. Indeed, a large trade literature that has followed Melitz (2003) shows that exporting firms are larger and more productive (e.g., Bernard et al. 2003; Bernard and Jensen 2004; Eaton et al. 2004; Yeaple 2005). In this literature, trade liberalization implies a reallocation of resources among the most productive firms. In another strand of the literature, learning-by-doing and externalities, technical innovation through imports of intermediate goods, and managerial efforts are other possible sources of productivity improvements that have been evidenced by different theoretical models (e.g., Ethier 1982; Markusen 1989; Grossman and Helpman 1991; Schmidt 1997; Kasahara and Rodrigue 2008).

In parallel, there is a large body of empirical evidence that suggests that more integrated firms - which are defined as firms that both export and import-are larger, more productive and pay higher wages (e.g., Muûls and Pisu 2009; Kasahara and Lapham 2013; Smeets and Warzynski 2013; De Hoyos and Iacovone 2013). Nevertheless, the first analysis that identified these firms as integrated into GVCs was Baldwin and Yan (2014). They find that Canadian firms that integrated into a GVC benefited from a rise in productivity by $5 \%$ as compared with their counterparts during the first year, and by $9 \% 4$ years later. By contrast, firms that left a GVC experienced a decrease in their productivity of $1 \%$ in the first year and $8 \% 4$ years later.

Whereas the integration of a firm into a GVC can take a number of forms, the vast majority of the empirical literature focuses on one particular form of GVC linkage: processing trade. For Feng et al. (2016), an increased use of imported intermediate inputs helps firms develop the volume and the scope of their exports.

The origin of imports plays an important role in the destination of exports. Indeed, importing intermediary inputs from high-income countries increases the probability of exporting to high-income countries. Therefore, under financial constraints, Manova and Yu (2016) find that firms are more likely to conduct more processing trade and pure assembly, whereas value added and profitability increase with ordinary trade. Dai et al. (2016) point out the fact that processing activities are linked to lower fixed costs of exporting. In Yu (2015), input and output tariff reductions in China induced an increase in firm-level productivity, but this impact decreased with the share of a firm's processing imports. Thus, although a lower fixed cost of exporting and improved trade policy favored processing activities, this induced lower firm-level productivity.

According to Manova and Yu (2016), a large part of Chinese exports comes from foreign affiliates instead of domestic firms. Among these foreign affiliates, Lu et al. (2010) show that non-exporters are more productive than are exporters. In line with the literature, they find the opposite is true for the non-foreign affiliates. Ju and Yu (2015) calculate an "upstreamness" index for all industries using the number of stages that the product will go through before reaching its final use. They find that upstream firms are more capital-intensive and that productivity and profitability are higher for these firms. For the MENA region, Del Prete et al. (2017) perform a micro firm-level analysis_-based on the World Bank Enterprise Survey data for 
Egypt, Morocco, and Algeria-and show that the performance of firms, measured by several indicators, is positively associated with internationalization and GVC participation.

On another front, there is growing evidence that an adverse business environment impedes firms' performance (e.g., Dollar et al. 2005; Van Biesebroeck 2005; Hallward-Driemeier et al. 2006; Fernandes 2008; Goedhuys et al. 2010; Augier et al. 2012; Bah and Fang 2015) and export activity (e.g., Berman and Héricourt 2010; Commander and Svejnar 2011). In these studies, the business environment in which firms operate-access to credit; regulatory and institutional environment; and infrastructure-play a crucial role in their performance but with considerable heterogeneity. These studies mainly focused on total factor productivity, labor productivity, export status, and ownership, while a firm's integration into a GVC was never addressed.

At the trade policy level, while tariffs on manufactured products are low in industrialized countries and are decreasing in developing countries, low tariffs that are repeated along the value chain can represent a significant cost for exporting firms (OECD 2018). Moreover, as has been argued in the literature, business environment characteristics are a fixed cost that affects exporters, while tariffs are a variable cost. This is why we examine how these characteristics exert a differential effect on sectors with low versus high tariffs: We analyze the extent to which a better business environment can counter-balance the negative effect of higher tariffs or amplify the positive effect of low tariffs with respect to the likelihood of a firm's integrating into a GVC.

Hence, our study provides a bridge between two active literatures on GVCs and the business environment. Using a comprehensive firm-level dataset from the World Bank Enterprise Survey (WBES) between 2006 and 2017, ${ }^{1}$ we use four different definitions of what constitutes a firm's integration into a GVC to shed light on the importance of business environment in this integration process.

The contribution of the paper is threefold: First, it provides a range of measures of the characteristics of firms that would identify a firm as integrated into a GVC. Second, it examines an array of business environment variables that are likely to influence the likelihood of a firm's integration into a GVC. Third, we examine this process separately for small and large firms and for sectors with high versus low tariffs. To our knowledge this is one of the first studies to examine the impact of the business environment on a firm's integration into a GVC, with a special focus on the MENA and EAP countries. Nevertheless, instead of establishing a causal link between the business environment and firms' integration into a GVC, we test more precisely the correlates between GVC linkages and a range of business environment measures.

Our main findings show that, in general, the number of days that are required to pay taxes, the number of procedures that are necessary to register property, and the time to export and to import have a significantly negative association with a firm's integration into a GVC. More heterogeneity is observed at the regional level

\footnotetext{
${ }^{1}$ See "Appendix 1" for the list of surveys included for each country.
} 


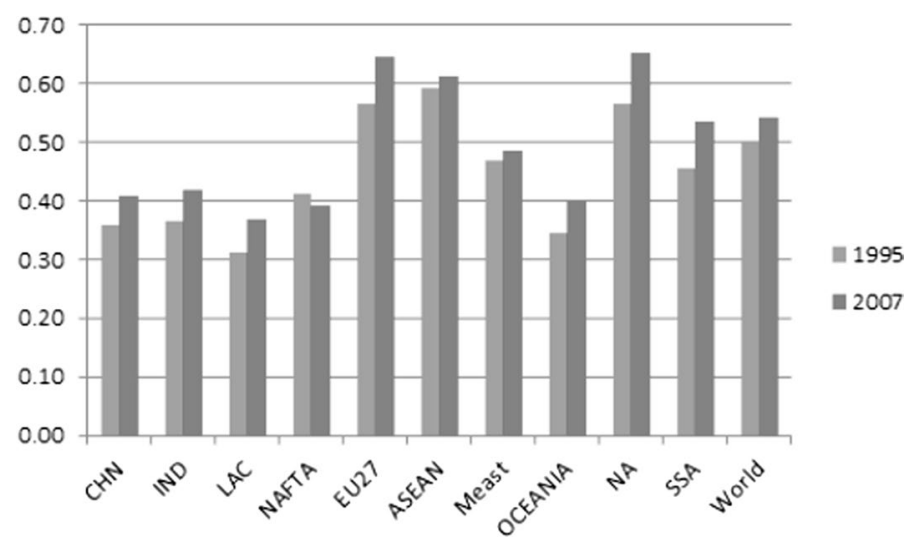

Fig. 1 GVC participation (by region). Source: Del Prete et al. (2017)

and at the firm-size level and for sectors with high versus low tariffs. Indeed, while small firms in the MENA region suffer more from access to finance, tax procedures, obtaining electricity, and trade procedures, those of the EAP region do not. When trade policy is taken into consideration, firms that operate in high-tariff sectors are likely to benefit more from a better business environment and hence be able to integrate into a GVC.

The remainder of the paper is organized as follows: Sect. 2 presents some descriptive statistics on GVCs and the business environment. Section 3 describes the methodology. Section 4 presents our empirical findings; and Sect. 5 concludes.

\section{Stylized Facts}

At the world level, according to Del Prete et al. (2017), GVC participation (defined as the sum of the foreign value-added share and the indirect value-added exports' share) has been increasing in most regions, from around 50\% in 1995 to 54\% 2007 worldwide. ASEAN countries are highly integrated in GVCs (Fig. 1). Interestingly and following the results of Foster-McGregor et al. (2015), North Africa has some of the highest rates of GVC participation, matching the levels found in Europe (65\% in 2007) - thanks to the development of automotive industries, particularly in Morocco.

In our paper, in order to define a GVC, we follow a new approach that is based on three main pieces of evidence: First, as has been highlighted by the literature, exporters and importers are fewer, bigger, and more productive that are non-tradeinvolved enterprises. Second, a foreign-ownership status may be an indicator of integration into a GVC, as foreign-owned firms may serve as exporting platforms for foreign countries. Third, an international certification may also be required in vertically fragmented production processes, which provides another indicator of GVC integration. 


\begin{tabular}{|c|c|c|c|}
\hline GVC1 & GVC2 & GVC3 & GVC4 \\
$=$ & $=$ & $=$ & $=$ \\
Exporter & Exporter & Exporter & Exporter \\
+ & + & + & + \\
Importer & Importer & Importer & Importer \\
& + & + & + \\
& & Foreign & Foreign \\
& Certification & Capital & Capital \\
& & & + \\
& & & Certification \\
\hline
\end{tabular}

Fig. 2 GVC definitions. Source: Authors' own elaboration

Table 1 Distribution of firm characteristics for all developing countries. Source: Authors' own elaboration using the WBES dataset (with weights)

\begin{tabular}{llllll}
\hline & Domestic (\%) & $\begin{array}{l}\text { Exporter-only } \\
(\%)\end{array}$ & $\begin{array}{l}\text { Importer-only } \\
(\%)\end{array}$ & Two-way (\%) & Total (\%) \\
\hline FDI & & & & & \\
$\quad$ Not certified & 1.4 & 3.2 & 3.9 & 6.2 & 2.6 \\
$\quad$ Certified & 1.1 & 4.8 & 2.7 & 15.2 & 3.7 \\
No FDI & & & & & \\
$\quad$ Not certified & 75.9 & 43.9 & 75.1 & 39.8 & 67.0 \\
$\quad$ Certified & 21.6 & 48.1 & 18.3 & 38.8 & 26.7 \\
Total & 60.2 & 12.5 & 14.1 & 13.2 & 100 \\
\hline
\end{tabular}

These are the reasons why we adopt four definitions of the criteria for identify a firm as being integrated into a GVC: First, the least strict definition (GVC1) includes firms that export and import simultaneously. Second, two stricter definitions apply to firms that are simultaneously exporters and importers and that also have either an international certification (GVC2) or a share of its capital that is owned by a foreign firm (GVC3). The strictest definition (GVC4) combines the four criteria (see Fig. 2).

On the one hand, GVC2 and GVC3 can be seen as substitutes. Indeed, while certification is a token of the level of quality of goods, foreign investments in developing countries can be expensive and risky. Thus, rather than investing in a domestic firm, foreign companies may instead prefer to work with domestic certified firms at first in order to control and secure transactions across borders.

On the other hand, certification and foreign ownership can also be seen as complements (GVC4): Foreign companies with certification can invest in domestic firms and implement their certification in this new firm; or a domestic firm's initial possession of a certification can attract foreign company investments.

Our preferred definition is the strictest one, since it specifies that a firm has several characteristics-exporting; importing; possessing with a foreign certification; and having a foreign ownership participation - that increase its likelihood of participation in a GVC. In the empirical part of this paper, we will focus on the least and the most restrictive definitions-GVC1 and GVC4, respectively-since they embody the basic and advanced criteria levels of a firm's integration into a GVC. 
Table 2 Distribution of firms by alternative GVC characterizations (by region). Source: Authors' own elaboration using the WBES dataset (with weights)

\begin{tabular}{lcccc}
\hline & GVC1 $(\%)$ & GVC2 $(\%)$ & GVC3 $(\%)$ & GVC4 (\%) \\
\hline East Asia and Pacific & 9 & 6 & 3 & 2 \\
Europe and Central Asia & 27 & 15 & 5 & 3 \\
Latin American and Caribbean & 13 & 5 & 3 & 2 \\
Middle East and North Africa & 13 & 6 & 2 & 1 \\
South Asia & 7 & 3 & 0 & 0 \\
Sub-Saharan Africa & 15 & 7 & 4 & 2 \\
All & 13 & 7 & 3 & 2 \\
\hline
\end{tabular}

Table 1 shows the worldwide distribution of firms that can potentially be identified as integrated into a GVC, based on the different definitions and using survey weights. $^{2}$ As it was mentioned before, we rely on all available WBES between 2006 and 2017. As a starting point, a majority of the firms $(60.2 \%)$ produce and serve the domestic market only and thus do not qualify under any definition.

Exporters-only at the world level are in a minority: They represent only $12.5 \%$ of the total number of firms. This in line with Freund and Pierola (2015), who found that the top five firms make up $30 \%$ of total exports in different countries. These firms are often called "export superstars".

While importers are more frequent, those that engage in two-way trade activity-which identifies them as GVC1-represent $13.2 \%$ of the total number of firms. Moreover, more than $50 \%$ of those that engage in export activity or in two-trade activity have an international certification. For those firms that import-only, this share represents $21 \%$. By contrast, only $15.2 \%$ of the two-way firms have both an international certification and a foreign ownership. This shows that the strictest definition (GVC4) of being integrated into a GVC applies to a relatively small share of firms in our dataset: $2 \%(=13.2 \% \times 15.2 \%)$.

When we examine the regional dimensions of firms that are identified as being integrated into a GVC (Table 2), two features are worth mentioning: First, as we noted above, on average $2 \%$ of firms are two-way firms with a foreign ownership and an international certification. Second, internationally certified firms are chiefly concentrated in Europe. The MENA region performs slightly better than does SouthAsia. With $13 \%$ of firms having two-way trade activity, the MENA region is around the average of our sample. Yet, when our two regions of interest-MENA and EAP - are compared, we can conclude that when the definition of the identification of a firm as integrated into a GVC is stricter, the share of MENA firms that qualify shrinks to a greater extent than is true for EAP firms. This shows the extent to which EAP firms are more advanced in terms of GVC integration.

It is important to note that, in our sample, we find that larger firms are more likely to: have foreign capital investment (Fig. 3); obtain an international certification

\footnotetext{
${ }^{2}$ It is worth noting that this paper focuses only on the manufacturing sector.
} 


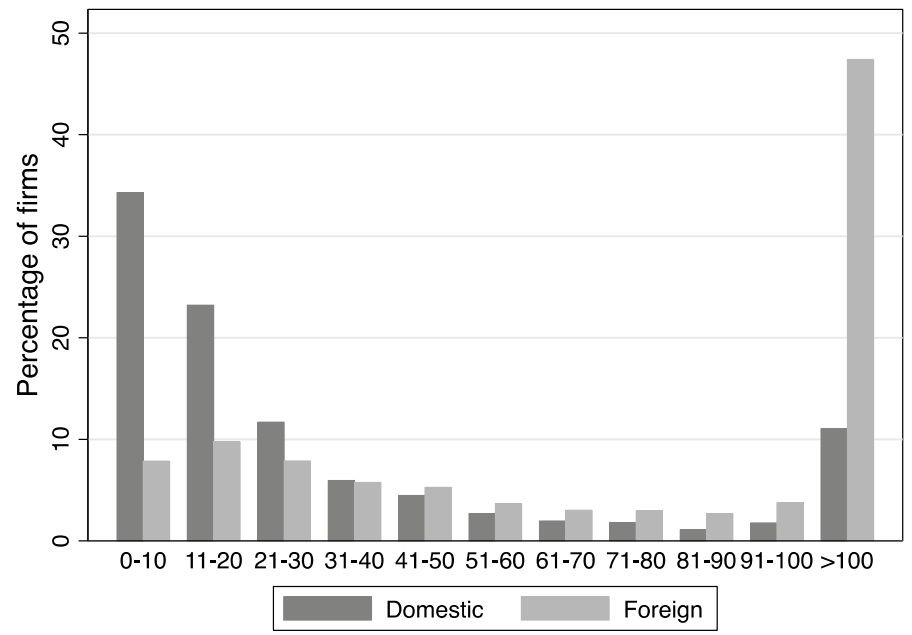

Fig. 3 Share of domestic and foreign firms by employment size. Source: Authors' own elaboration using the WBES dataset

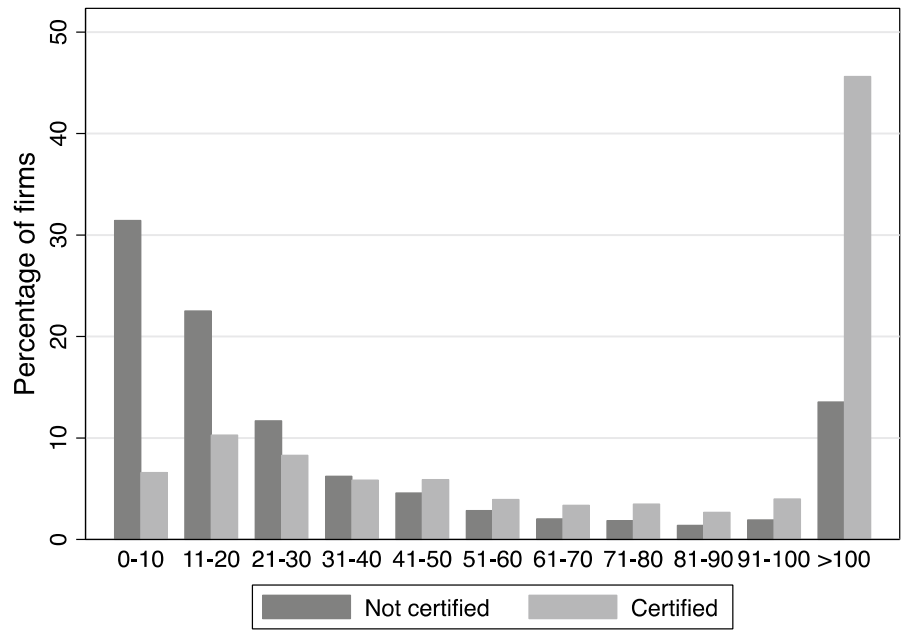

Fig. 4 Internationally certified versus not-certified firms by employment size. Source: Authors' own elaboration using the WBES dataset

(Fig. 4); have either a two-way trade activity and an international certification (Fig. 5) or a two-way trade activity and a foreign ownership (Fig. 6); or have all three aspects simultaneously (Fig. 7). This confirms that SMEs still face impediments that hinder their engagement in a GVC.

Table 3 presents the main obstacles that characterize the business environment in different regions based on the firms' perceptions. The most severe obstacles in the MENA region are chiefly political instability, electricity supply, access to finance, corruption, tax rates, and practices from the informal sector. This is 


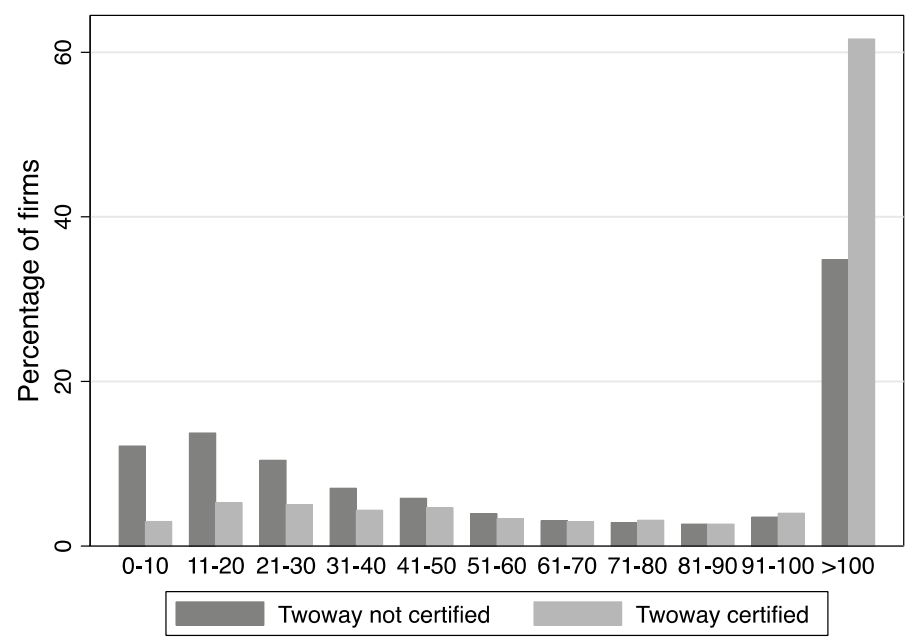

Fig. 5 Two-way firms: certified versus not certified by employment size. Source: Authors' own elaboration using the WBES dataset

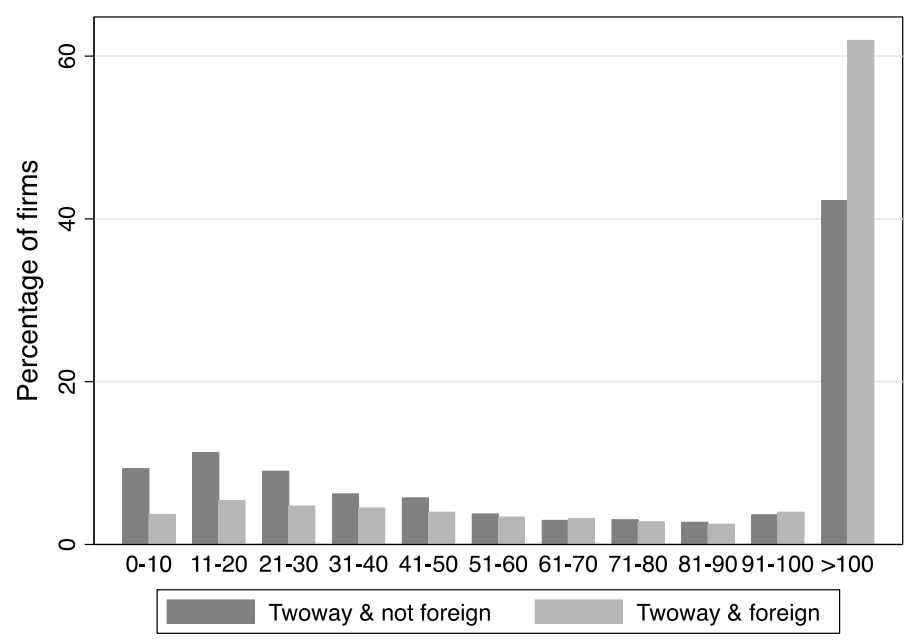

Fig. 6 Two-way firms with or without foreign capital by employment size. Source: Authors' own elaboration using the WBES dataset

similar to the EAP and the Latin America and the Caribbean (LAC) regions, where firms reported that the most severe obstacles are also tax rates, access to finance, and competition from the informal sector. Hence, most of the developing countries still suffer from several dimensions in their business environment, which in turn affects their performance and hence their engagement in GVCs.

Furthermore, the World Bank's Doing Business dataset for 2017 presents facts rather than perceptions and is presented in Table 4. For most of the indicators, 


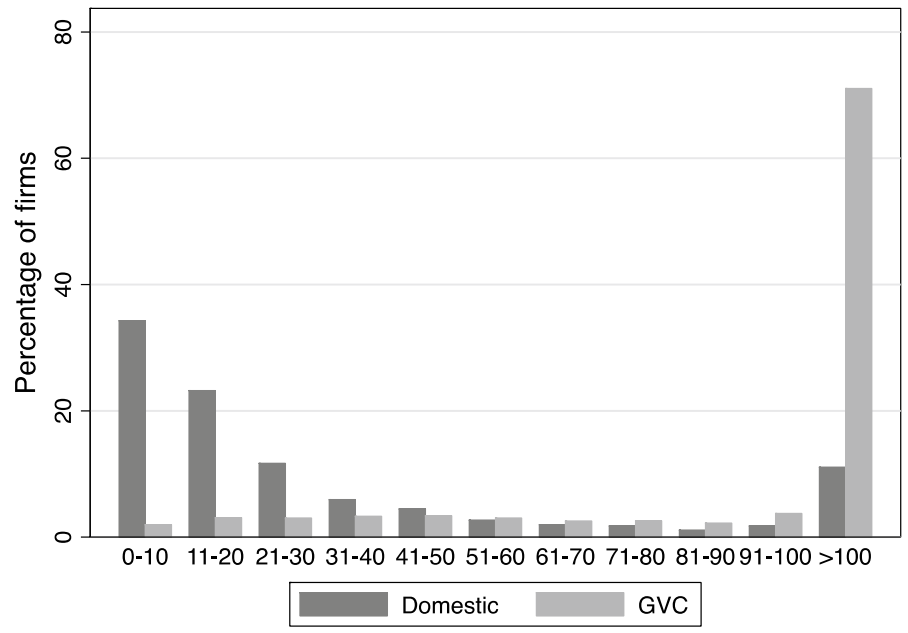

Fig. 7 Domestic versus GVC4 firms by employment size. Source: Authors' own elaboration using the WBES dataset

Table 3 Biggest obstacle in the business environment (by region). Source: Authors' own elaboration using the WBES dataset

\begin{tabular}{lccccccccc}
\hline & All & EAP & ECA & H-NON & H-OECD & LAC & MENA & SA & SSA \\
\hline Access to finance & 15.5 & 11 & 14.2 & 14.8 & 11.7 & 14.3 & 10.2 & 12.4 & 22.5 \\
Bus. licensing & 2.6 & 4.1 & 2.1 & 2 & 2.7 & 3.7 & 2.8 & 1.8 & 1.9 \\
Corruption & 7.4 & 8.7 & 7.9 & 3.7 & 2.6 & 8 & 7.8 & 9.3 & 8 \\
Courts & 1 & 1.2 & 1.6 & 0.4 & 1.5 & 1.2 & 1.1 & 0.4 & 0.5 \\
Crime, theft & 4 & 2.9 & 1.4 & 6.7 & 2.5 & 9.1 & 1.9 & 2.6 & 3.4 \\
Customs reg. & 3.9 & 2.7 & 3.4 & 7 & 1.1 & 4.7 & 3.8 & 1.9 & 4.8 \\
Electricity & 9.3 & 5.9 & 5.4 & 9.6 & 2.5 & 7.8 & 14.1 & 20.3 & 12.8 \\
Inadeq. workforce & 6.8 & 7.3 & 5.8 & 16.3 & 12.5 & 9.8 & 5.4 & 3.4 & 2.2 \\
Labor reg. & 3 & 3.1 & 1.8 & 3.5 & 8.7 & 3.6 & 2.8 & 5.1 & 1.1 \\
Political instab. & 11.3 & 10.9 & 13.1 & 3 & 9.2 & 6.9 & 28.4 & 17.9 & 9.8 \\
Pract. informal & 12.5 & 16.3 & 15.5 & 11.1 & 10.5 & 14.1 & 7.4 & 6.2 & 11.5 \\
Tax admin. & 3.7 & 3.3 & 4.7 & 2.4 & 5.5 & 2.7 & 1.6 & 2.7 & 4.5 \\
Tax rates & 12.4 & 11.3 & 18.6 & 14.6 & 22 & 10.1 & 8.3 & 6.9 & 9.2 \\
Transportation & 2.9 & 4.8 & 2.2 & 4 & 3.8 & 2.5 & 1.4 & 3.6 & 2.8 \\
\hline
\end{tabular}

Figures represent share of firms reporting each aspect as the biggest obstacle to their business

EAP (East Asia and Pacific), ECA (Europe and Central Asia), H-NON (High income: non-OECD), HOECD (High income: OECD), LAC (Latin America and Caribbean, MENA (Middle East and North Africa), SA (South-Asia), SSA (Sub-Saharan Africa) 
Table 4 Business environment, based on doing business. Source: Authors' own elaboration using the doing business dataset

\begin{tabular}{lrrrrrrr}
\hline & EAP & ECA & LAC & MENA & OECD & SSA & SA \\
\hline Time required to enforce a contract (days) & 534.4 & 528.1 & 763.5 & 663.3 & 548.5 & 664.2 & 1101.7 \\
Time required to resolve insolvency (years) & 2.4 & 2.0 & 2.9 & 3.0 & 1.8 & 3.0 & 2.6 \\
Time required to register property (days) & 66.4 & 24.9 & 61.8 & 34.6 & 24.3 & 59.6 & 112.7 \\
Time required to start a business (days) & 34.6 & 13.9 & 34.3 & 20.4 & 10.8 & 30.9 & 18.6 \\
Time to export (days) & 18.9 & 18.1 & 16.9 & 19.1 & 10.9 & 30.6 & 33.7 \\
Time to import (days) & 20.0 & 18.6 & 18.6 & 23.1 & 10.1 & 37.9 & 34.8 \\
Time to prepare and pay taxes (h) & 207.3 & 204.9 & 362.1 & 219.6 & 175.2 & 304.4 & 288.6 \\
Time required to obtain electrical service & 92.2 & 110.2 & 65.3 & 85.7 & 89.0 & 136.1 & 148.7 \\
$\quad$ (days) & & & & & & &
\end{tabular}

EAP stands for East Asia and Pacific, ECA Europe and Central Asia, LAC Latin America and Caribbean, MENA Middle East and North Africa, OECD OECD members, SSA Sub-Saharan Africa and SA South Asia

(a) Applied Tariff rate - simple mean (\%)

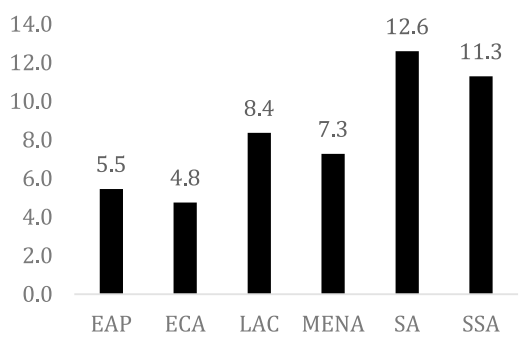

(b) Share of tariff lines with international peaks (\%)

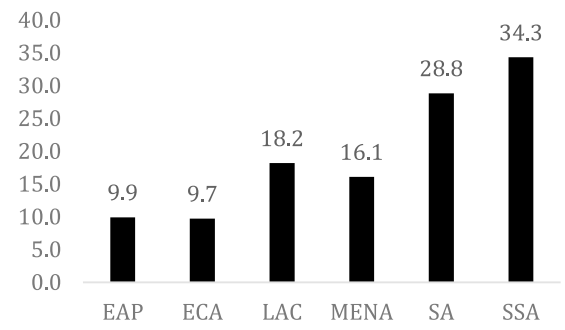

Fig. 8 Trade policy by region. a Applied Tariff rate-simple mean (\%). b Share of tariff lines with international peaks (\%). Note: EAP stands for East Asia and Pacific, ECA Europe and Central Asia, LAC Latin America and Caribbean, MENA Middle East and North Africa, SSA Sub-Saharan Africa and SA South Asia. Figures are averages between 2005 and 2017. Source: Authors' own elaboration using the World Development Indicators

the MENA region performs better than is true for the LAC and the Sub-Saharan Africa (SSA) regions and worse than EAP, Europe, and Central Asia regions.

A more detailed examination shows that the time that is needed to enforce contracts is longer in LAC and SSA than in MENA. But the time that is needed to resolve an insolvency is the longest in MENA and in SSA. While the time that is needed to register property is short in the MENA region, several countries do not have laws or do not enforce laws that are related to property rights. With respect to trade procedures, the time that is needed to export and to import is longer for the MENA region than for the LAC and EAP regions, which increases the cost of trade and helps explain why the MENA region still underperforms in exports. Finally, whereas the time that is needed to obtain electricity is shorter in the 
MENA region than in other regions, electricity is still reported as one of the most important challenges that is faced by firms (Table 3 ).

At the trade policy level, Fig. 8 shows that while the MENA region has a higher applied tariff rate and more tariff lines with international peaks than does the EAP region, both regions are more open than other developing regions: LAC and SSSA. Yet, as was mentioned above, low tariffs that are repeated along the value chain can represent a significant cost for exporting firms.

Overall, this descriptive analysis helps explain why the EAP region is more integrated into advanced GVCs than is the MENA region. Moreover, the latter countries are more protective, and their business environments are more deficient.

\section{Methodology}

We use a large firm-level survey dataset (between 2006 and 2017) that includes information on a firm's location, sales, value added, output, exports, imports, date of creation, location, investment, etc. and the firm's perception of its business environment. Specifically, we use The Enterprise Surveys that are conducted by the World Bank for a large dataset that includes a substantial number of developing countries (see "Appendix 1" for the list of countries and years included). This survey covers firms in all manufacturing sectors.

We investigate the effects of different dimensions of the business environment on the likelihood of firm-level integration into a GVC while taking into account firm characteristics. Since we have a range of definitions-GVC1 to GVC4 (see Fig. 2) of the characteristics of a firm that identify it as integrated into a GVC, we run separate regressions for each of these definitions. Given that the presence or absence of these GVC-linked characteristics is a discrete variable (equal to 0 or 1), the probit model will be used to estimate the following regressions:

$$
\begin{aligned}
& \operatorname{Prob}\left(X_{i j l c t}\right)=\left\{\begin{array}{l}
1 \text { if } \beta_{0}+\beta_{1}^{\prime} V_{i j l c t}+\beta_{2}^{\prime} X_{i j l c t}+\delta_{j}+\delta_{c}+\delta_{t}+\varepsilon_{i j l c t}>0 \\
0 \text { otherwise }
\end{array}\right. \\
& \operatorname{Prob}\left(X_{i j l c t}\right)=\left\{\begin{array}{l}
1 \text { if } \beta_{0}+\sum_{k} \beta_{1}^{\prime}\left(V_{i j l c t} * I^{k}\right)+\beta_{2}^{\prime} X_{i j l c t}+\delta_{j}+\delta_{c}+\delta_{t}+\varepsilon_{i j l c t}>0 \\
0 \text { otherwise }
\end{array}\right.
\end{aligned}
$$

where $i, j, l, c$ and $t$ represent, respectively, the firm, the industry, the location (region), the country and year; $X_{i j l c t}$, is a vector of control variables that include a firm's characteristics (size, age, tariff, etc.); $\delta_{j}, \delta_{c}$ and $\delta_{t}$ are industry, country and year fixed effects, respectively; $I^{k}$ is a dummy variable that identifies the firm type according to its relative employee size (equal to 1 for a firm that is at or above the 75th percentile, and 0 otherwise) or its presence in a sector with relatively high or low tariffs (with the 75 th percentile again being the dividing point); and $\varepsilon_{i j l c t}$ is an unobserved error term. The business environment indicators $-V_{i j l c t}$-are industrycountry averages of firm-level observations while excluding the individual firm's own responses. As a consequence, the business environment in a specific industry $j$ 
and country $c$ is assumed to be common for all firms in that industry and country in a certain year.

Our vector of business environment measures includes eight groups of variables that are likely to be associated with the firms that are likely to have GVC linkages: ${ }^{3}$

1. Infrastructural support, such as access to electricity;

2. Access to finance;

3. Fiscal issues, such as tax administration and tax policy;

4. Contract enforcement and insolvency resolution;

5. Ease of obtaining permits;

6. Importance of the informal sector;

7. International trade procedures; and

8. Security for a firm's goods and its minority investors.

It is worth noting that for each dimension, we introduce two sets of variables (when available): The first set encompasses factual variables from the WBES that take the value of 1 if that business environment variable affects the firm and zero otherwise. The second set of variables come from the Doing Business dataset that measures the characteristics of the business environment. The variables are summarized in "Appendix 2". As for tariffs, we use a simple average of the most-favorednation tariff at the 2-digit level; the data come from the UNCTAD Trade Analysis Information System (TRAINS).

Since the effect of business environment variables is not homogenous across different firms, we distinguish between small and large firms and also between firms that operate in sectors with low or high tariff rates. Such distinctions are crucial for developing insights as to how to promote the integration of new and small and medium firms into GVCs.

As is discussed in Fernandes (2008) the absence of time variability prevents us from using firm-level fixed effects estimation, and from exploring the impact of changes over time; and this also influences the probability of finding significant coefficients. In line with the literature, this procedure then has implications for issues of potential endogeneity. It is therefore important to note that our results should be interpreted more as correlates between measures of GVC linkage and the array of business environment variables.

Moreover, partially to overcome this problem, we use industry-country averages minus the individual firm's own responses to reduce the risk of endogeneity between the business environment and firm-level GVC status. We also use information on the survey design and weights in order to control for the potential over-sampling of large firms in the database.

\footnotetext{
${ }^{3}$ For the variable definitions, see "Appendix 2".
} 
Table 5 Pooled regressions for all developing countries. Source: Authors' own elaboration based on STATA output

\begin{tabular}{|c|c|c|c|}
\hline & & GVC1 & GVC4 \\
\hline \multicolumn{4}{|c|}{ 1-Infrastructure } \\
\hline Factual & Generator & $\begin{array}{l}0.166 \\
(0.135)\end{array}$ & $\begin{array}{l}-0.312 * \\
(0.174)\end{array}$ \\
\hline Doing business & Proc. obtaining elec. & $\begin{array}{l}-0.756^{*} \\
(0.415)\end{array}$ & $\begin{array}{l}2.174 \\
(1.586)\end{array}$ \\
\hline \multicolumn{4}{|l|}{ 2-Finance } \\
\hline \multirow[t]{2}{*}{ Factual } & Self finan. & $\begin{array}{l}-1.175^{* *} \\
(0.563)\end{array}$ & $\begin{array}{l}-0.047 \\
(0.273)\end{array}$ \\
\hline & Bank finan. & $\begin{array}{l}0.925^{* * *} \\
(0.394)\end{array}$ & $\begin{array}{l}0.233 \\
(0.381)\end{array}$ \\
\hline Doing business & Credit regis. cov. & $\begin{array}{l}-0.011^{* * *} \\
(0.004)\end{array}$ & $\begin{array}{l}0.002 \\
(0.008)\end{array}$ \\
\hline \multicolumn{4}{|l|}{ 3-Fiscal } \\
\hline \multirow[t]{2}{*}{ Doing business } & Number of pay & $\begin{array}{l}-0.043 \\
(0.079)\end{array}$ & $\begin{array}{l}0.151^{*} \\
(0.088)\end{array}$ \\
\hline & Time to pay tax & $\begin{array}{l}-0.557 * * * \\
(0.011)\end{array}$ & $\begin{array}{l}-1.590 \text { *** } \\
(0.019)\end{array}$ \\
\hline \multicolumn{4}{|l|}{ 4-Enforcing } \\
\hline \multirow[t]{2}{*}{ Doing business } & Proc. enf. contracts & $\begin{array}{l}3.726^{*} \\
(2.190)\end{array}$ & $\begin{array}{l}0.651 \\
(1.555)\end{array}$ \\
\hline & Time res. insolvency & $\begin{array}{l}-0.134 * \\
(0.066)\end{array}$ & $\begin{array}{l}0.444^{* * * *} \\
(0.162)\end{array}$ \\
\hline \multicolumn{4}{|l|}{ 5-Permits } \\
\hline \multirow[t]{2}{*}{ Doing business } & Proc start bus & $\begin{array}{l}-0.821 * * * \\
(0.311)\end{array}$ & $\begin{array}{l}-1.547 \text { *** } \\
(0.551)\end{array}$ \\
\hline & Proc regis prop. & $\begin{array}{l}-0.978^{* *} \\
(0.415)\end{array}$ & $\begin{array}{l}-1.986^{* *} \\
(0.805)\end{array}$ \\
\hline \multicolumn{4}{|l|}{ 6-Informality } \\
\hline \multirow[t]{2}{*}{ Factual } & Informality & $\begin{array}{l}0.109 \\
(0.120)\end{array}$ & $\begin{array}{l}-0.447^{* *} \\
(0.227)\end{array}$ \\
\hline & Sales inf. pay & $\begin{array}{l}0.010 \\
(0.006)\end{array}$ & $\begin{array}{l}0.011^{*} \\
(0.006)\end{array}$ \\
\hline \multicolumn{4}{|c|}{ 7-Trade procedures } \\
\hline \multirow[t]{4}{*}{ Doing business } & Doc to exp. & $\begin{array}{l}0.681 \\
(0.416)\end{array}$ & $\begin{array}{l}0.363 \\
(0.362)\end{array}$ \\
\hline & Doc to imp. & $\begin{array}{l}0.013 \\
(0.193)\end{array}$ & $\begin{array}{l}0.551 \\
(0.479)\end{array}$ \\
\hline & Time to exp. & $\begin{array}{l}-0.977 * * * \\
(0.123)\end{array}$ & $\begin{array}{l}-1.544 \text { *** } \\
(0.407)\end{array}$ \\
\hline & Time to imp. & $\begin{array}{l}-0.754 * * * \\
(0.073)\end{array}$ & $\begin{array}{l}-0.865^{* * * *} \\
(0.304)\end{array}$ \\
\hline \multicolumn{4}{|l|}{ 8-Security } \\
\hline Factual & Break & $\begin{array}{l}0.013 \\
(0.015)\end{array}$ & $\begin{array}{l}-0.011 \\
(0.021)\end{array}$ \\
\hline Doing business & Protec inv. (Liab.) & $\begin{array}{l}0.120 * * * \\
(0.016)\end{array}$ & $\begin{array}{l}0.292 * * * \\
(0.040)\end{array}$ \\
\hline
\end{tabular}

Each line represents an individual regression. Robust standard errors in parentheses

Errors are clustered by country and year for the doing business variables *** $p<0.01$; ** $p<0.05$; * $p<0.1$

All regressions include country, sector, and year dummy variables 


\section{Empirical Findings}

Tables 5 and 6 show the association between the business environment variables and the likelihood of a firm having the characteristics that would identify it as being integrated into a GVC: for all developing countries, and for our two regions of interest: MENA and EAP. For the sake of brevity, we report results for the probit models for only the least (GVC1) and the most (GVC4) restrictive definitions of the likelihood of a firm's being associated with a GVC. In Tables 7, 8, 9 and 10, we report the results of the probit model by firm size and for sectors with low and high tariffs. ${ }^{4}$ Given the large number of tables, the results for the other GVC definitions are available from the authors on request. ${ }^{5}$

First, for all developing countries (Table 5), at the infrastructure level, owning a generator is associated negatively with firms in the GVC4 category. Indeed, the existence of a generator means that electricity is either not stable or not strong enough, which reduces the likelihood that a firm will be a part of a GVC. This is in line with the literature on electricity and growth of firms, where one of the starkest examples of infrastructure failures is poor electricity. The latter can significantly reduce output, as electricity is essential for lights, motors, and machines (Hulten et al. 2006).

At the institutional level, the number of procedures to get electricity is associated negatively and significantly with the firms in the GVC1 category. These results highlight the fact that firms, in order to benefit from electricity connections, have to bear the cost of heavy and lengthy procedures.

When the MENA region is compared to the EAP region (Table 6), a generator is positively associated with GVC1 in the MENA region and negatively with GVC4 in the EAP region. The result for the MENA region is interesting since generators may be perceived as a substitute for the problem of weak electricity for the MENA region's firms that just export and import (GVC1). But a reliable source of electricity is not essential to be part of the more advanced GVC4 (as is true for the EAP).

When firm size is taken into consideration for all developing countries (Table 7), integrating into the simple GVC1 is positively associated with generators for large firms only. Yet, in the MENA region, for both small and large firms, generators are positively associated with the firms that qualify for the simplest GVC1 definition (see Table 9). While electricity procedures represent a barrier for small and large firms in the MENA region (and small more than large ones), they are insignificant in the EAP region: The former region still suffers from several red tape barriers to obtain electricity.

When we compare sectors with low and high tariffs in all developing countries (Table 8), integrating into a GVC1 is positively associated with generators only for firms in the high-tariff sector. For the regions, Table 10 shows that for the MENA

\footnotetext{
${ }^{4}$ Larger firms are those whose employee size is at or above the 75 th percentile, and small is below the 75 th percentile. High tariffs similarly correspond to a level that is at or above the 75 th percentile, and low is below the 75 th percentile.

5 As a robustness check, regressions were also run with OLS and are also available upon request.
} 
Table 6 Separate regressions for MENA and EAP. Source: Authors' own elaboration based on STATA output

\begin{tabular}{|c|c|c|c|c|c|}
\hline & & \multicolumn{2}{|l|}{ GVC1 } & \multicolumn{2}{|l|}{ GVC4 } \\
\hline & & MENA & EAP & MENA & EAP \\
\hline \multicolumn{6}{|c|}{ 1-Infrastructure } \\
\hline Factual & Generator & $\begin{array}{l}1.308 * * * \\
(0.294)\end{array}$ & $\begin{array}{l}0.025 \\
(0.232)\end{array}$ & $\begin{array}{l}0.598 \\
(0.572)\end{array}$ & $\begin{array}{l}-0.625^{* *} \\
(0.258)\end{array}$ \\
\hline Doing business & Proc. obtaining elec. & $\begin{array}{l}-1.343 \\
(1.023)\end{array}$ & $\begin{array}{l}-1.508 \\
(1.009)\end{array}$ & $\begin{array}{l}-0.712 \\
(0.603)\end{array}$ & $\begin{array}{l}-0.673 \\
(0.542)\end{array}$ \\
\hline \multicolumn{6}{|l|}{ 2-Finance } \\
\hline \multirow[t]{2}{*}{ Factual } & Self finan. & $\begin{array}{l}-0.045 \\
(0.349)\end{array}$ & $\begin{array}{l}-1.596^{* *} \\
(0.682)\end{array}$ & $\begin{array}{l}1.574 * * * \\
(0.579)\end{array}$ & $\begin{array}{l}-0.209 \\
(0.351)\end{array}$ \\
\hline & Bank finan. & $\begin{array}{l}-0.434 \\
(0.518)\end{array}$ & $\begin{array}{l}1.422^{* * *} \\
(0.651)\end{array}$ & $\begin{array}{l}-2.004^{*} \\
(1.066)\end{array}$ & $\begin{array}{l}0.408 \\
(0.543)\end{array}$ \\
\hline Doing business & Credit regis. cov & $\begin{array}{l}0.045^{* * * *} \\
(0.009)\end{array}$ & $\begin{array}{l}0.005 \\
(0.007)\end{array}$ & $\begin{array}{l}0.031 * * * \\
(0.004)\end{array}$ & $\begin{array}{l}0.000 \\
(0.003)\end{array}$ \\
\hline \multicolumn{6}{|l|}{ 3-Fiscal } \\
\hline \multirow[t]{2}{*}{ Doing business } & Number of pay. & $\begin{array}{l}-0.601 * * * \\
(0.159)\end{array}$ & $\begin{array}{l}-0.689^{* * * *} \\
(0.135)\end{array}$ & $\begin{array}{l}-0.327 * * \\
(0.134)\end{array}$ & $\begin{array}{l}-0.306^{* * * *} \\
(0.102)\end{array}$ \\
\hline & Time to pay tax & $\begin{array}{l}-0.190 \\
(0.182)\end{array}$ & $\begin{array}{l}-0.229 \\
(0.187)\end{array}$ & $\begin{array}{l}-0.139 \\
(0.104)\end{array}$ & $\begin{array}{l}-0.139 \\
(0.096)\end{array}$ \\
\hline \multicolumn{6}{|l|}{ 4-Enforcing } \\
\hline \multirow[t]{2}{*}{ Doing business } & Proc. Enf. contracts & $\begin{array}{l}-3.671 * * * \\
(0.783)\end{array}$ & $\begin{array}{l}-3.911^{* * * *} \\
(0.814)\end{array}$ & $\begin{array}{l}-1.498 * * * \\
(0.487)\end{array}$ & $\begin{array}{l}-1.594 * * * \\
(0.493)\end{array}$ \\
\hline & Time res. insolvency & $\begin{array}{l}-0.114 \\
(0.541)\end{array}$ & $\begin{array}{l}0.014 \\
(0.224)\end{array}$ & $\begin{array}{l}-0.393 \\
(0.327)\end{array}$ & $\begin{array}{l}0.045 \\
(0.122)\end{array}$ \\
\hline \multicolumn{6}{|l|}{ 5-Permits } \\
\hline \multirow[t]{2}{*}{ Doing business } & Proc start bus. & $\begin{array}{l}-0.524 \\
(0.401)\end{array}$ & $\begin{array}{l}-0.771 * * \\
(0.374)\end{array}$ & $\begin{array}{l}-0.017 \\
(0.289)\end{array}$ & $\begin{array}{l}-0.152 \\
(0.274)\end{array}$ \\
\hline & Proc regis prop. & $\begin{array}{l}-0.046 \\
(0.546)\end{array}$ & $\begin{array}{l}-0.071 \\
(0.589)\end{array}$ & $\begin{array}{l}-0.024 \\
(0.355)\end{array}$ & $\begin{array}{l}0.148 \\
(0.324)\end{array}$ \\
\hline \multicolumn{6}{|l|}{ 6-Informality } \\
\hline \multirow[t]{2}{*}{ Factual } & Informality & $\begin{array}{l}-0.007 \\
(0.208)\end{array}$ & $\begin{array}{l}0.275 \\
(0.175)\end{array}$ & $\begin{array}{l}-1.384 * * \\
(0.544)\end{array}$ & $\begin{array}{l}-0.326 \\
(0.280)\end{array}$ \\
\hline & Sales inf. pay. & $\begin{array}{l}0.020 \\
(0.027)\end{array}$ & $\begin{array}{l}0.021 * * \\
(0.010)\end{array}$ & $\begin{array}{l}-0.007 \\
(0.008)\end{array}$ & $\begin{array}{l}0.016 * * \\
(0.007)\end{array}$ \\
\hline \multicolumn{6}{|c|}{ 7-Trade procedures } \\
\hline \multirow[t]{4}{*}{ Doing business } & Doc to exp. & $\begin{array}{l}-1.470 * * * \\
(0.319)\end{array}$ & $\begin{array}{l}-0.828^{*} \\
(0.442)\end{array}$ & $\begin{array}{l}-0.837 * * * \\
(0.316)\end{array}$ & $\begin{array}{l}-0.245 \\
(0.311)\end{array}$ \\
\hline & Doc to imp. & $\begin{array}{l}-1.520 * * * \\
(0.367)\end{array}$ & $\begin{array}{l}-1.185^{* * * *} \\
(0.298)\end{array}$ & $\begin{array}{l}-0.847 * * * \\
(0.301)\end{array}$ & $\begin{array}{l}-0.513 * * * \\
(0.192)\end{array}$ \\
\hline & Time to exp. & $\begin{array}{l}0.669 \\
(1.011)\end{array}$ & $\begin{array}{l}-0.197 \\
(0.556)\end{array}$ & $\begin{array}{l}0.881 \\
(0.673)\end{array}$ & $\begin{array}{l}-0.348 \\
(0.239)\end{array}$ \\
\hline & Time to imp. & $\begin{array}{l}0.424 \\
(1.120)\end{array}$ & $\begin{array}{l}-0.542 * * \\
(0.252)\end{array}$ & $\begin{array}{l}1.214^{*} \\
(0.696)\end{array}$ & $\begin{array}{l}-0.348^{* * * *} \\
(0.128)\end{array}$ \\
\hline \multicolumn{6}{|l|}{ 8-Security } \\
\hline Factual & Break & $\begin{array}{l}-0.104 * * * \\
(0.031)\end{array}$ & $\begin{array}{l}0.036 \\
(0.027)\end{array}$ & $\begin{array}{l}-0.087 \\
(0.063)\end{array}$ & $\begin{array}{l}-0.012 \\
(0.029)\end{array}$ \\
\hline
\end{tabular}




\begin{tabular}{|c|c|c|c|c|c|}
\hline & & \multicolumn{2}{|l|}{ GVC1 } & \multicolumn{2}{|l|}{ GVC4 } \\
\hline & & MENA & EAP & MENA & EAP \\
\hline Doing business & Protec inv. (Liab.) & $\begin{array}{l}0.223 * * * \\
(0.063)\end{array}$ & $\begin{array}{l}0.055 \\
(0.037)\end{array}$ & $\begin{array}{l}0.161 * * * \\
(0.025)\end{array}$ & $\begin{array}{l}0.030 \\
(0.019)\end{array}$ \\
\hline
\end{tabular}

Each line represents an individual regression. Robust standard errors in parentheses

Errors are clustered by country and year for the doing business variables

$* * * p<0.01 ; * * p<0.05 ; * p<0.1$

All regressions include country, sector, and year dummy variables

region firms that operate in high-tariff sectors are more associated with generators than is true for their counterparts that operate in low-tariff sectors for GVC1 linkages. For the EAP region, firms in high-tariff sectors are negatively associated with generators for GVC4 linkages.

Second, for access to finance, in general self-financing is negatively associated with GVC1 linkages, whereas bank financing is positively associated with it. Indeed, while the former might be small in terms of amount and sustainability, the latter can help firms expand. Therefore, making access to finance easier can increase the likelihood of a firm's integrating into a GVC.

When firm size is taken into consideration, bank financing is positively associated with GVC1 linkages and GVC4 linkages for larger firms only.

At the regional level, while both smaller and larger firms are positively affected by self-financing to be part of a GVC, the likelihood of being part of a GVC is negatively affected by bank financing for larger firms in the MENA region. Indeed, the latter are still suffering from several impediments that prevent them from having a sustainable and significant access to finance. This is in line with El-Said et al. (2015), who showed that limited access to finance exerts a negative effect on trade performance and especially for SMEs, since it prevents them from expanding, becoming more productive, and hence improving their trade performance. This might be attributed to the high cost of borrowing and the complexity of the related procedures. A bank account increases the probability for large firm to integrate a GVC dimension. For the EAP region, the results are different since bank financing is positively linked to the most restrictive definition of the GVC (GVC4).

Further, financial infrastructure is important, as credit registry coverage is positively linked with the integration into a GVC in the MENA region. Firms that operate in high-tariff sectors benefit more from self-financing and suffer more from bank-financing in the MENA region. This is not the case for the EAP region, where both bank financing and credit registry coverage boost integration into a GVC4 in high-tariff sectors (see Table 10).

Third, as for fiscal policy for all developing countries, costly and time-consuming procedures do matter for the likelihood of being integrated into a GVC. Indeed, the time that is necessary to pay taxes has a negative and significant association with a firm's likely integration onto a GVC, with a higher effect for GVC4 than for GVC1. 
Table 7 Pooled results for all developing countries-by firm size. Source: Authors' own elaboration based on STATA output

\begin{tabular}{|c|c|c|c|c|c|}
\hline & & \multicolumn{2}{|l|}{ GVC1 } & \multicolumn{2}{|l|}{ GVC4 } \\
\hline & & Small & Large & Small & Large \\
\hline \multicolumn{6}{|c|}{ 1-Infrastructure } \\
\hline Factual & Generator & $\begin{array}{l}-0.079 \\
(0.168)\end{array}$ & $\begin{array}{l}0.808^{* * * *} \\
(0.136)\end{array}$ & $\begin{array}{l}-0.726^{* *} \\
(0.283)\end{array}$ & $\begin{array}{l}0.187 \\
(0.184)\end{array}$ \\
\hline Doing business & Proc. obtaining elec. & $\begin{array}{l}-0.414 \\
(0.594)\end{array}$ & $\begin{array}{l}-0.339 \\
(0.572)\end{array}$ & $\begin{array}{l}-0.876^{* *} \\
(0.446)\end{array}$ & $\begin{array}{l}-0.540 \\
(0.442)\end{array}$ \\
\hline \multicolumn{6}{|l|}{ 2-Finance } \\
\hline \multirow[t]{2}{*}{ Factual } & Self finan. & $\begin{array}{l}-1.263^{* *} \\
(0.561)\end{array}$ & $\begin{array}{l}-0.741 \\
(0.480)\end{array}$ & $\begin{array}{l}-0.101 \\
(0.268)\end{array}$ & $\begin{array}{l}0.032 \\
(0.303)\end{array}$ \\
\hline & Bank finan. & $\begin{array}{l}0.816^{*} \\
(0.421)\end{array}$ & $\begin{array}{l}1.415^{* * *} \\
(0.405)\end{array}$ & $\begin{array}{l}-0.134 \\
(0.544)\end{array}$ & $\begin{array}{l}1.039 * * * \\
(0.330)\end{array}$ \\
\hline Doing business & Credit regis. cov & $\begin{array}{l}0.009 \\
(0.006)\end{array}$ & $\begin{array}{l}0.014 * * \\
(0.006)\end{array}$ & $\begin{array}{l}-0.006 \\
(0.006)\end{array}$ & $\begin{array}{l}0.001 \\
(0.006)\end{array}$ \\
\hline \multicolumn{6}{|l|}{ 3-Fiscal } \\
\hline \multirow[t]{2}{*}{ Doing business } & Number of pay. & $\begin{array}{l}-0.194 \\
(0.120)\end{array}$ & $\begin{array}{l}-0.102 \\
(0.112)\end{array}$ & $\begin{array}{l}-0.150 \\
(0.098)\end{array}$ & $\begin{array}{l}-0.003 \\
(0.092)\end{array}$ \\
\hline & Time to pay tax & $\begin{array}{l}-0.109 \\
(0.130)\end{array}$ & $\begin{array}{l}-0.070 \\
(0.130)\end{array}$ & $\begin{array}{l}-0.181^{*} \\
(0.105)\end{array}$ & $\begin{array}{l}-0.100 \\
(0.107)\end{array}$ \\
\hline \multicolumn{6}{|l|}{ 4-Enforcing } \\
\hline \multirow[t]{2}{*}{ Doing business } & Proc. enf. contracts & $\begin{array}{l}-1.953^{* * *} \\
(0.595)\end{array}$ & $\begin{array}{l}-1.878^{* * *} \\
(0.597)\end{array}$ & $\begin{array}{l}-1.822^{* * *} \\
(0.449)\end{array}$ & $\begin{array}{l}-1.677 \text { *** } \\
(0.444)\end{array}$ \\
\hline & Time res. insolvency & $\begin{array}{l}-0.111 \\
(0.196)\end{array}$ & $\begin{array}{l}0.121 \\
(0.166)\end{array}$ & $\begin{array}{l}-0.116 \\
(0.136)\end{array}$ & $\begin{array}{l}0.200^{*} \\
(0.116)\end{array}$ \\
\hline \multicolumn{6}{|l|}{ 5-Permits } \\
\hline \multirow[t]{2}{*}{ Doing business } & Proc start bus. & $\begin{array}{l}-0.460^{* * *} \\
(0.210)\end{array}$ & $\begin{array}{l}-0.364^{*} \\
(0.203)\end{array}$ & $\begin{array}{l}-0.341 \\
(0.209)\end{array}$ & $\begin{array}{l}-0.122 \\
(0.192)\end{array}$ \\
\hline & Proc regis prop. & $\begin{array}{l}-0.073 \\
(0.341)\end{array}$ & $\begin{array}{l}0.013 \\
(0.343)\end{array}$ & $\begin{array}{l}-0.046 \\
(0.274)\end{array}$ & $\begin{array}{l}0.201 \\
(0.287)\end{array}$ \\
\hline \multicolumn{6}{|l|}{ 6-Informality } \\
\hline \multirow[t]{2}{*}{ Factual } & Informality & $\begin{array}{l}0.003 \\
(0.127)\end{array}$ & $\begin{array}{l}0.587 * * * \\
(0.168)\end{array}$ & $\begin{array}{l}-0.617 \text { ** } \\
(0.288)\end{array}$ & $\begin{array}{l}-0.058 \\
(0.193)\end{array}$ \\
\hline & Sales inf. pay. & $\begin{array}{l}0.006 \\
(0.007\end{array}$ & $\begin{array}{l}0.028^{* *} \\
(0.012)\end{array}$ & $\begin{array}{l}0.008 \\
(0.008)\end{array}$ & $\begin{array}{l}0.0160^{*} \\
(0.009)\end{array}$ \\
\hline \multicolumn{6}{|c|}{ 7-Trade procedures } \\
\hline \multirow[t]{4}{*}{ Doing business } & Doc to exp. & $\begin{array}{l}-0.524^{*} \\
(0.287)\end{array}$ & $\begin{array}{l}-0.414 \\
(0.282)\end{array}$ & $\begin{array}{l}-0.800^{* * *} \\
(0.307)\end{array}$ & $\begin{array}{l}-0.522^{*} \\
(0.302)\end{array}$ \\
\hline & Doc to imp. & $\begin{array}{l}-0.703^{* * * *} \\
(0.245)\end{array}$ & $\begin{array}{l}-0.570^{* *} \\
(0.233)\end{array}$ & $\begin{array}{l}-0.563 * * * \\
(0.173)\end{array}$ & $\begin{array}{l}-0.300^{*} \\
(0.172)\end{array}$ \\
\hline & Time to exp. & $\begin{array}{l}-0.226 \\
(0.194)\end{array}$ & $\begin{array}{l}-0.135 \\
(0.170)\end{array}$ & $\begin{array}{l}-0.319^{* * *} \\
(0.152)\end{array}$ & $\begin{array}{l}-0.144 \\
(0.137)\end{array}$ \\
\hline & Time to imp. & $\begin{array}{l}-0.341^{*} \\
(0.185)\end{array}$ & $\begin{array}{l}-0.255 \\
(0.164)\end{array}$ & $\begin{array}{l}-0.401 * * * \\
(0.117)\end{array}$ & $\begin{array}{l}-0.236^{* *} \\
(0.102)\end{array}$ \\
\hline \multicolumn{6}{|l|}{ 8-Security } \\
\hline Factual & Break & $\begin{array}{l}0.009 \\
(0.016)\end{array}$ & $\begin{array}{l}0.031 \\
(0.027)\end{array}$ & $\begin{array}{l}-0.050 \\
(0.037)\end{array}$ & $\begin{array}{l}0.028 \\
(0.024)\end{array}$ \\
\hline
\end{tabular}


Table 7 (continued)

\begin{tabular}{|c|c|c|c|c|c|}
\hline & & \multicolumn{2}{|l|}{ GVC1 } & \multicolumn{2}{|l|}{ GVC4 } \\
\hline & & Small & Large & Small & Large \\
\hline Doing business & Protec inv. (Liab.) & $\begin{array}{l}0.021 \\
(0.034)\end{array}$ & $\begin{array}{l}0.002 \\
(0.035)\end{array}$ & $\begin{array}{l}0.027 \\
(0.026)\end{array}$ & $\begin{array}{l}0.080 * * * \\
(0.027)\end{array}$ \\
\hline
\end{tabular}

Each line represents an individual regression. Robust standard errors in parentheses

Errors are clustered by country and year for the doing business variables

$* * * p<0.01 ; * * p<0.05 ; * p<0.1$

All regressions include country, sector, and year dummy variables

Non-transparent tax rates do not provide a permissive climate for businesses to grow and thrive.

When EAP is compared to MENA, Table 6 shows that GVC4 in MENA is more affected by the number of payments than is true for firms in EAP. When we control for the firm size, Table 9 shows that small firms in both MENA and EAP are more affected by number of payments and time that is needed to pay taxes than are their larger counterparts. Table 10 confirms that tax administration measured by these two variables exerts a higher negative effect for integration in GVC1 for firms in high-tariff sectors.

In all of the regressions, the effect in the MENA region is always greater in magnitude than for the EAP region: Institutional arrangements in EAP are in general better than in MENA.

Fourth, for all developing countries, the results of contract enforcement are not robust (Table 5). When we focus on only MENA and EAP, the enforcement of contracts matters for integration into GVCs regardless of the firm's size or the level of tariff (Table 6) with a higher effect in MENA than in EAP.

When we control for the size of firms, the number of procedures to enforce contracts has a higher negative effect for integration into GVCs for smaller firms in general (Table 7) and for the EAP region (Table 9). Yet, in the MENA region, larger firms are slightly more affected by these variables. The time that is needed to resolve an insolvency is significantly negative for the MENA region (more negative for GVC4 linkages than for GVC1 linkages). Resolving insolvency matters for firms, since a good insolvency regime should prevent premature liquidation of businesses and discourage lenders from issuing high-risk loans. Hence, firms become more sustainable and are more likely to be part of a GVC.

Fifth, for obtaining permits, for all developing countries, it is worth noting that the procedures to register property and to start businesses are negative and significant for the two definitions of GVC as well as for all types of firms (regardless of the tariff level and of the firm's size). However, as was mentioned above, the effect is stronger for smaller firms that face more impediments while registering (Table 7): Only large firms can pay the high level of costs of permits and are thereby more likely to be a part of a GVC. The effect is also stronger for GVC4 linkages in hightariff sectors: Improving such procedures will help firms that operate in protected sectors. 
Table 8 Pooled results for all developing countries-by tariff level. Source: Authors' own elaboration based on STATA output

\begin{tabular}{|c|c|c|c|c|c|}
\hline & & \multicolumn{2}{|l|}{ GVC1 } & \multicolumn{2}{|l|}{ GVC4 } \\
\hline & & Low tariff & High tariff & Low tariff & High tariff \\
\hline \multicolumn{6}{|l|}{ 1-Infrastructure } \\
\hline Factual & Generator & $\begin{array}{l}0.106 \\
(0.155)\end{array}$ & $\begin{array}{l}0.354 * * * \\
(0.120)\end{array}$ & $\begin{array}{l}-0.312^{*} \\
(0.189)\end{array}$ & $\begin{array}{l}-0.311 \\
(0.208)\end{array}$ \\
\hline Doing business & Proc. obtaining elec. & $\begin{array}{l}-0.374 \\
(0.573)\end{array}$ & $\begin{array}{l}-0.367 \\
(0.597)\end{array}$ & $\begin{array}{l}-0.628 \\
(0.433)\end{array}$ & $\begin{array}{l}-0.473 \\
(0.427)\end{array}$ \\
\hline \multicolumn{6}{|l|}{ 2-Finance } \\
\hline \multirow[t]{2}{*}{ Factual } & Self finan. & $\begin{array}{l}-1.162^{* * *} \\
(0.573)\end{array}$ & $\begin{array}{l}-1.251^{* *} \\
(0.517)\end{array}$ & $\begin{array}{l}-0.051 \\
(0.280)\end{array}$ & $\begin{array}{l}-0.024 \\
(0.259)\end{array}$ \\
\hline & Bank finan. & $\begin{array}{l}0.918 * * \\
(0.432)\end{array}$ & $\begin{array}{l}0.947 * * * \\
(0.350)\end{array}$ & $\begin{array}{l}0.215 \\
(0.409)\end{array}$ & $\begin{array}{l}0.323 \\
(0.434)\end{array}$ \\
\hline Doing business & Credit regis. cov & $\begin{array}{l}0.011^{*} \\
(0.006)\end{array}$ & $\begin{array}{l}0.009 \\
(0.006)\end{array}$ & $\begin{array}{l}-0.006 \\
(0.006)\end{array}$ & $\begin{array}{l}0.002 \\
(0.006)\end{array}$ \\
\hline \multicolumn{6}{|l|}{ 3-Fiscal } \\
\hline \multirow[t]{2}{*}{ Doing business } & Number of pay. & $\begin{array}{l}-0.159 \\
(0.116)\end{array}$ & $\begin{array}{l}-0.158 \\
(0.120)\end{array}$ & $\begin{array}{l}-0.055 \\
(0.095)\end{array}$ & $\begin{array}{l}-0.054 \\
(0.090)\end{array}$ \\
\hline & Time to pay tax & $\begin{array}{l}-0.099 \\
(0.128)\end{array}$ & $\begin{array}{l}-0.104 \\
(0.136)\end{array}$ & $\begin{array}{l}-0.151 \\
(0.113)\end{array}$ & $\begin{array}{l}-0.158 \\
(0.119)\end{array}$ \\
\hline \multicolumn{6}{|l|}{ 4-Enforcing } \\
\hline \multirow[t]{2}{*}{ Doing business } & Proc. enf. contracts & $\begin{array}{l}-1.865^{* * * *} \\
(0.595)\end{array}$ & $\begin{array}{l}-1.863^{* * * *} \\
(0.597)\end{array}$ & $\begin{array}{l}-1.624 * * * \\
(0.486)\end{array}$ & $\begin{array}{l}-1.639 * * * \\
(0.495)\end{array}$ \\
\hline & Time res. insolvency & $\begin{array}{l}-0.064 \\
(0.184)\end{array}$ & $\begin{array}{l}-0.033 \\
(0.184)\end{array}$ & $\begin{array}{l}0.061 \\
(0.128)\end{array}$ & $\begin{array}{l}-0.024 \\
(0.119)\end{array}$ \\
\hline \multicolumn{6}{|l|}{ 5-Permits } \\
\hline \multirow[t]{2}{*}{ Doing business } & Proc start bus. & $\begin{array}{l}-0.432^{* *} \\
(0.204)\end{array}$ & $\begin{array}{l}-0.433^{* *} \\
(0.202)\end{array}$ & $\begin{array}{l}-0.222 \\
(0.204)\end{array}$ & $\begin{array}{l}-0.222 \\
(0.200)\end{array}$ \\
\hline & Proc regis prop. & $\begin{array}{l}-0.055 \\
(0.339)\end{array}$ & $\begin{array}{l}-0.059 \\
(0.336)\end{array}$ & $\begin{array}{l}0.074 \\
(0.286)\end{array}$ & $\begin{array}{l}0.068 \\
(0.278)\end{array}$ \\
\hline \multicolumn{6}{|l|}{ 6-Informality } \\
\hline \multirow[t]{2}{*}{ Factual } & Informality & $\begin{array}{l}0.160 \\
(0.125)\end{array}$ & $\begin{array}{l}-0.083 \\
(0.148)\end{array}$ & $\begin{array}{l}-0.477 * \\
(0.246)\end{array}$ & $\begin{array}{l}-0.317 \\
(0.235)\end{array}$ \\
\hline & Sales inf. pay. & $\begin{array}{l}0.009 \\
(0.008)\end{array}$ & $\begin{array}{l}0.012 * \\
(0.007)\end{array}$ & $\begin{array}{l}0.009 \\
(0.007)\end{array}$ & $\begin{array}{l}0.0159 * \\
(0.009)\end{array}$ \\
\hline \multicolumn{6}{|c|}{ 7-Trade procedures } \\
\hline \multirow[t]{4}{*}{ Doing business } & Doc to exp. & $\begin{array}{l}-0.489^{*} \\
(0.276)\end{array}$ & $\begin{array}{l}-0.474 \\
(0.297)\end{array}$ & $\begin{array}{l}-0.594 * \\
(0.313)\end{array}$ & $\begin{array}{l}-0.615^{*} \\
(0.324)\end{array}$ \\
\hline & Doc to imp. & $\begin{array}{l}-0.634 * * * \\
(0.234)\end{array}$ & $\begin{array}{l}-0.622^{* *} \\
(0.245)\end{array}$ & $\begin{array}{l}-0.347 * * \\
(0.177)\end{array}$ & $\begin{array}{l}-0.370 * * \\
(0.177)\end{array}$ \\
\hline & Time to exp. & $\begin{array}{l}-0.178 \\
(0.173)\end{array}$ & $\begin{array}{l}-0.164 \\
(0.179)\end{array}$ & $\begin{array}{l}-0.162 \\
(0.144)\end{array}$ & $\begin{array}{l}-0.170 \\
(0.149)\end{array}$ \\
\hline & Time to imp. & $\begin{array}{l}-0.298 * \\
(0.171)\end{array}$ & $\begin{array}{l}-0.282 \\
(0.175)\end{array}$ & $\begin{array}{l}-0.277^{* *} \\
(0.115)\end{array}$ & $\begin{array}{l}-0.295 * * \\
(0.125)\end{array}$ \\
\hline \multicolumn{6}{|l|}{8 -Security } \\
\hline Factual & Break & $\begin{array}{l}0.019 \\
(0.017)\end{array}$ & $\begin{array}{l}-0.005 \\
(0.022)\end{array}$ & $\begin{array}{l}-0.005 \\
(0.022)\end{array}$ & $\begin{array}{l}-0.028 \\
(0.036)\end{array}$ \\
\hline
\end{tabular}




\begin{tabular}{|c|c|c|c|c|c|}
\hline & & \multicolumn{2}{|l|}{ GVC1 } & \multicolumn{2}{|l|}{ GVC4 } \\
\hline & & Low tariff & High tariff & Low tariff & High tariff \\
\hline Doing business & Protec inv. (Liab.) & $\begin{array}{l}0.026 \\
(0.034)\end{array}$ & $\begin{array}{l}-0.001 \\
(0.034)\end{array}$ & $\begin{array}{l}0.052 * \\
(0.028)\end{array}$ & $\begin{array}{l}0.043 * \\
(0.026)\end{array}$ \\
\hline
\end{tabular}

Each line represents an individual regression. Robust standard errors in parentheses

Errors are clustered by country and year for the doing business variables

$* * * p<0.01 ; * * p<0.05 ; * p<0.1$

All regressions include country, sector, and year dummy variables

While the number of procedures to register property matter more for MENA, the procedures to start a business are more significant in EAP. Indeed, registering property and property rights are still problems in the MENA region.

Sixth, for all developing countries the informal sector exerts a negative effect on the likelihood of a firm's participation in a GVC4 (Table 5). While this result holds for GVC4 linkages in the MENA region, it is not significant in the EAP region. This general result holds because many firms in the developing countries prefer to remain in the informal sector so as to escape the red tape cost and excessive tax payments of the formal sector, which hinders their expansion and reduces their participation in a GVC. When size is considered, smaller firms and those in low-tariff sectors suffer more from informality.

However, in most of the regressions, informal payments are positively associated with GVC linkages, especially in the EAP region. This raises a question as to the effect of corruption since-sometimes in developing countries-such payments can overcome the problem of red-tape barriers and speed-up most of the procedures.

Seventh, with regard to trade procedures, the only negative and significant variable is the number of documents to export and to import for all of the GVC definitions taken into consideration, with a slightly higher effect for small firms (Table 9) and those in high-tariff sectors (Table 10) for GVC1 in the MENA region. The number of documents seems to prevent firms from starting a trade activity since the firms bear the costs of the bureaucratic trade procedures. This is why improving customs procedures will encourage firms to belong to a GVC. This can occur by enhancing transparency, avoiding the duplication of documentation requirements, and automating data submission procedures. It is worth noting that the correlation with costs might represent self-selection of firms: Only those that can overcome the costs are likely to integrate into a GVC.

Finally, the protection of minority investors and the share of the value of products that is lost in transit due to breakage or spoilage have a significant effect on GVC linkages in the MENA region. While breakage is insignificant in the EAP region, protection of minority investors is positive and significant especially for GVC4 linkages in most of the regressions. This protection is important since it reduces uncertainty and hence increases the likelihood of investing, expanding, and hence being in a position to integrate into a GVC.

Table 11 provides a summary of the important results with respect to the likelihood that a firm is integrated into a GVC4. 


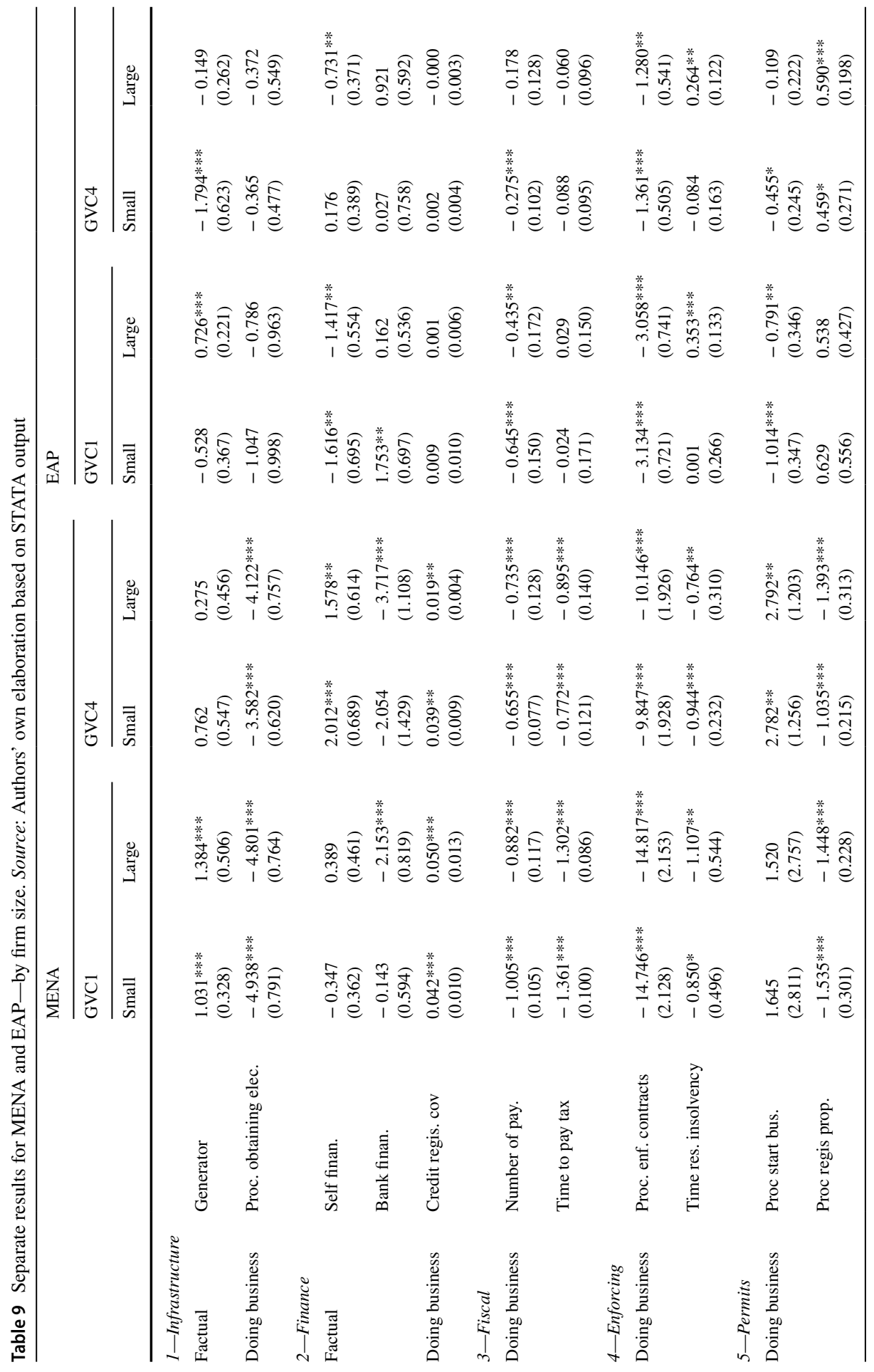




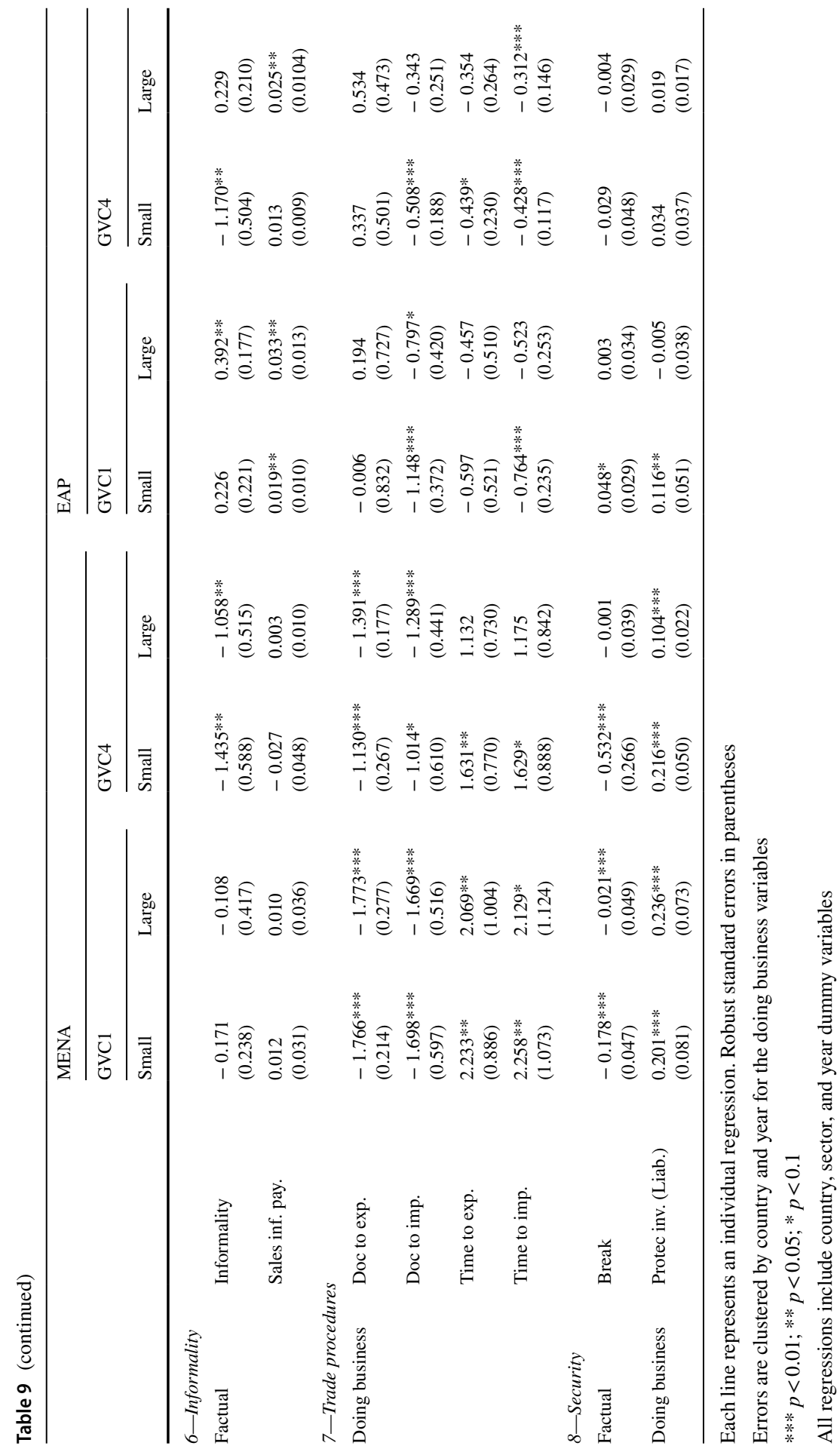




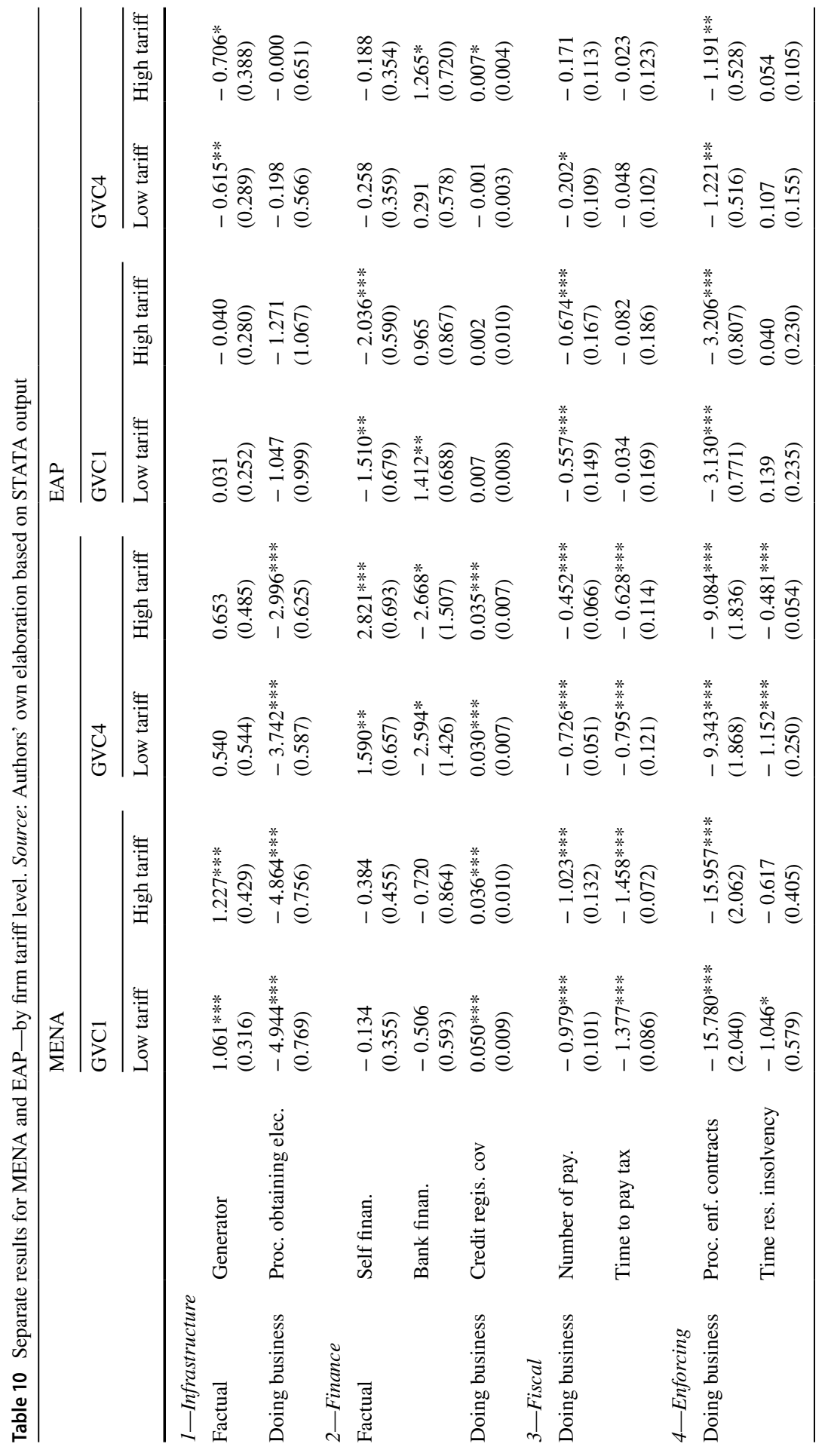




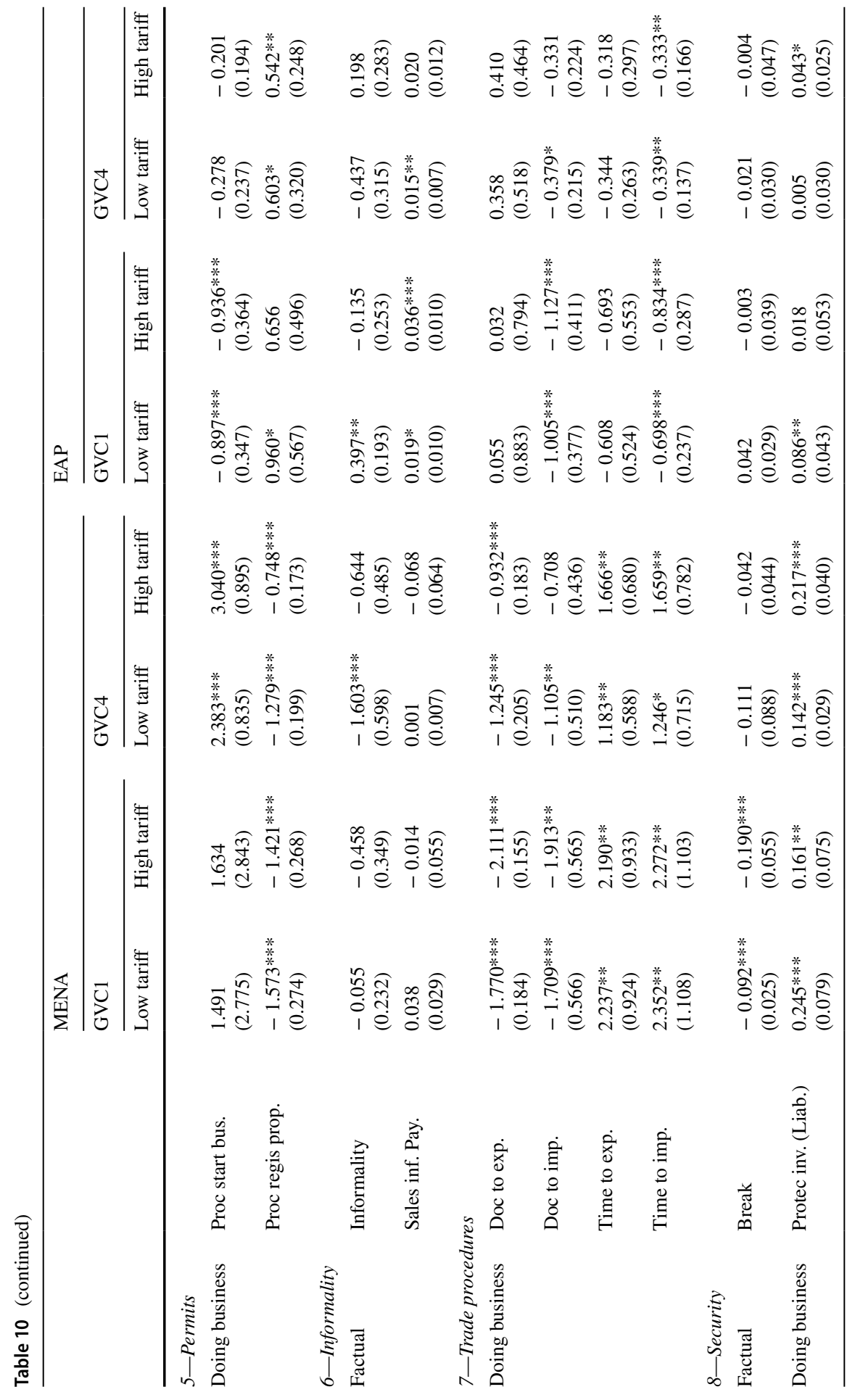




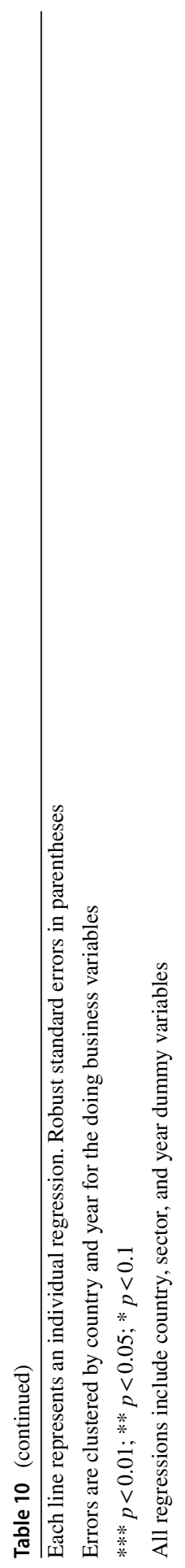




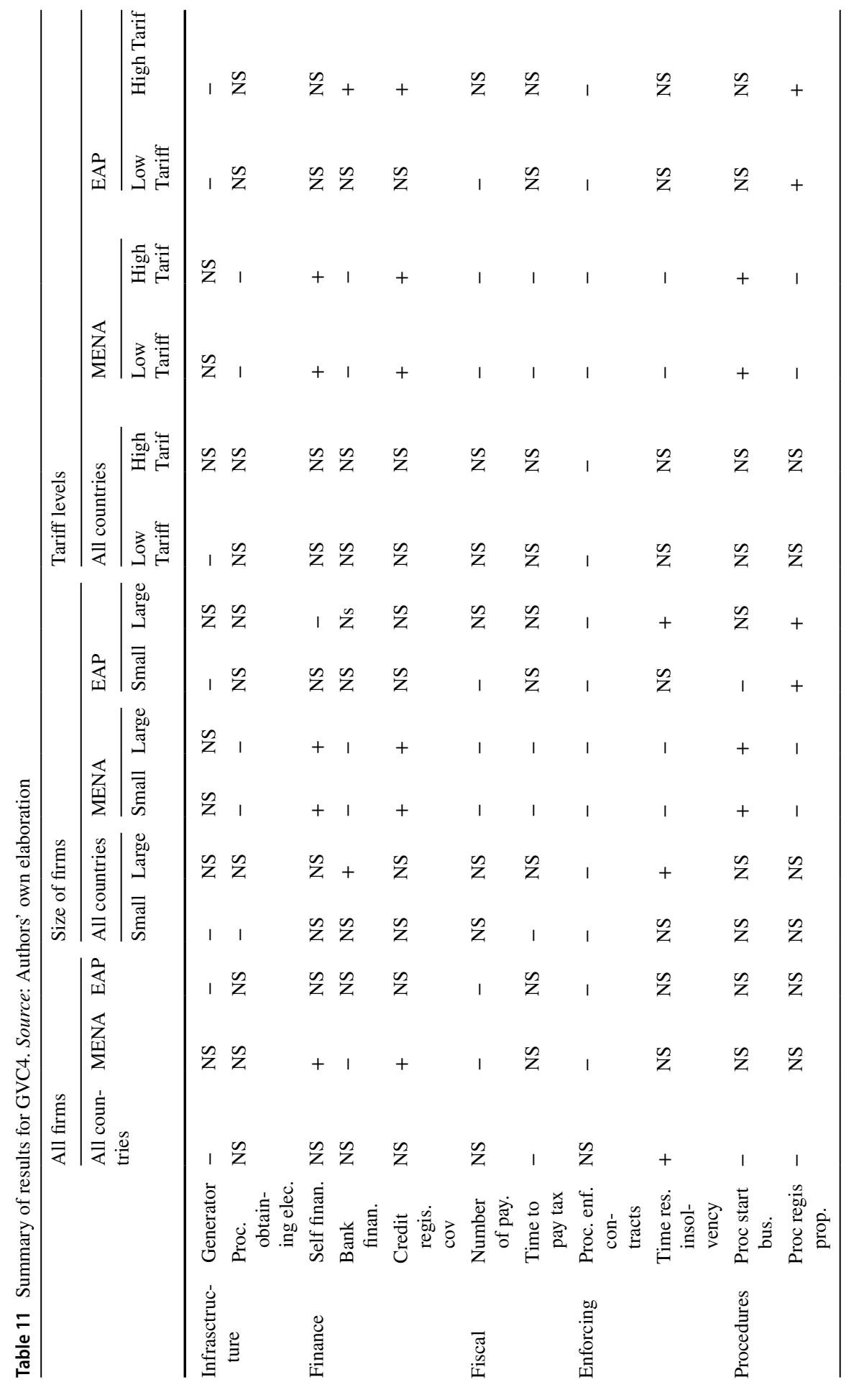




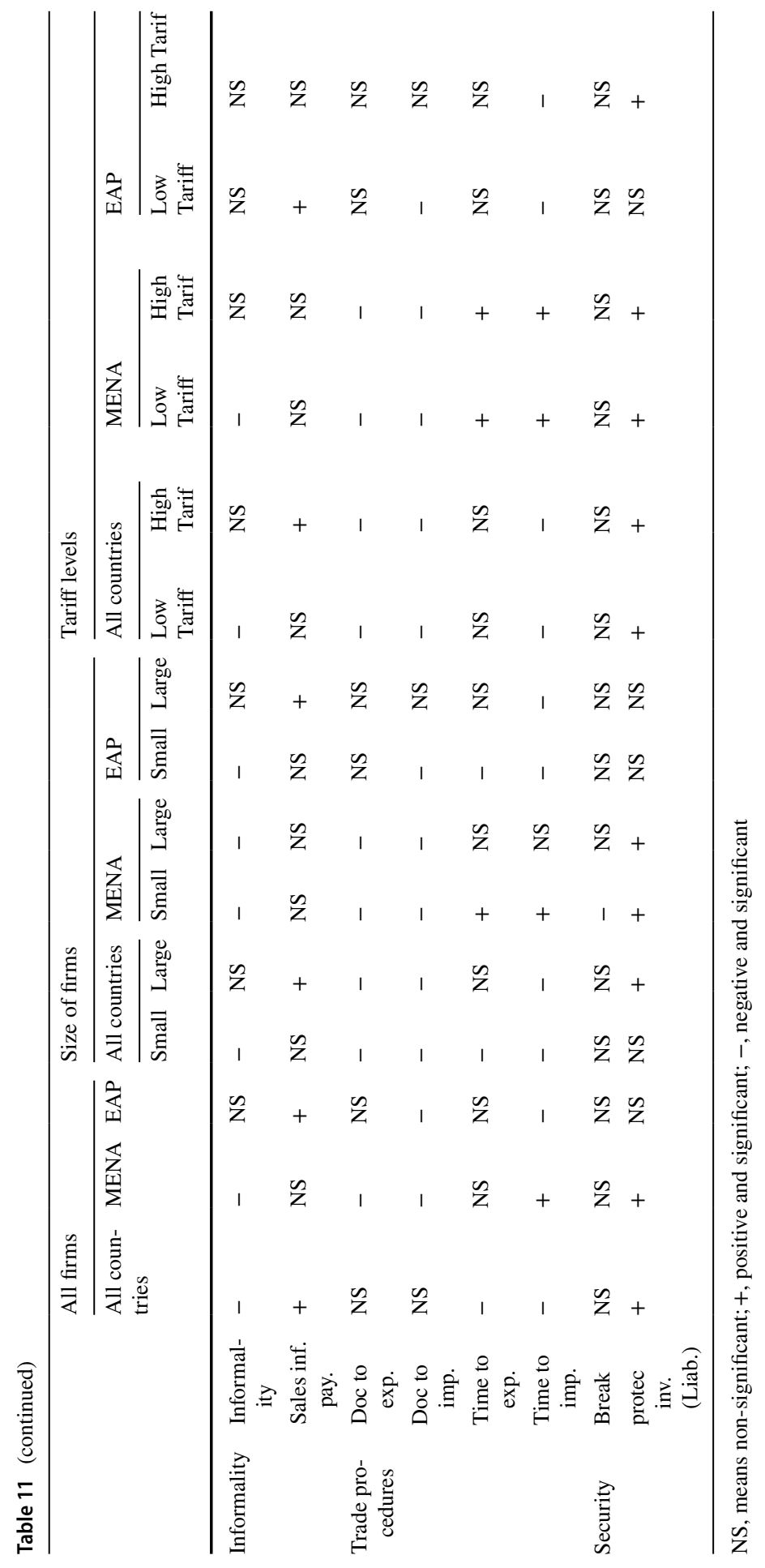




\section{Conclusion and Policy Recommendations}

This study assesses the effect of a country's business environment on the likelihood that a firm will be part of a global value chain. With the use of a comprehensive firm-level dataset from the World Bank Enterprise Survey (WBES), with a special focus on the MENA and EAP region countries), the contribution of the paper is threefold: First, it provides a range of measures of the characteristic of firms that would identify a firm as likely to be integrated into a GVC. Second, it examines the impact of an array of business environment variables-infrastructure; access to finance; fiscal policy; enforcement of contracts; ease of obtaining permits; the importance of the informal sector; trade procedures; and security for a firm's goods and investors - on the likelihood of a firm integrating into a GVC. Third, we compare two emerging regions that have different performances with respect to GVCs: MENA and EAP. The former is only modestly integrated, while the latter has experienced significant increases in its GVC linkages.

Our main findings show that the number of procedures to obtain electricity, the number of tax payments, the time to resolve an insolvency, the number of documents that are needed to export and import, and the number of procedures to register property exert a negative impact on the likelihood of a firm's integrating into a GVC. When tariff level and employment size are taken into consideration, firms in hightariff sectors and smaller firms seem to suffer more from these impediments, which reduce their likelihood of being part of a GVC — especially when more restrictive criteria (GVC4) are used to define integrating into a GVC.

From a policy perspective, this paper illuminates numerous relevant issues in the MENA region, especially with respect to the GVC linkages that are likely to increase the productivity of firms and boost their expansion. There are four relevant sets of policies:

First, a more transparent fiscal policy will help firms become part of a GVC. Second, improving infrastructure and especially spending for electrical power generation and distribution will allow firms to specialize in more complex products that might be possible with a regular and more sustainable source of power. Third, enforcing and implementing transparent laws for registering property is crucial for firms to be part of a GVC. Finally, regulating the informal sector so as to reduce the negative effects that are implied by the practices of informal firms should also be on the agenda of developing countries to increase their firms' engagement with GVCs.

Our paper is in line with Rodrik (2018), who argued that developing countries should rely more on "domestic integration". The latter means improving the capabilities and the fundamentals of the economy through investment in human capital, the business environment, and governance. Thus, more efforts should be deployed to strengthen the connection between the highly productive global firms, potential local suppliers, and the domestic labor force. This cannot take place without improving the business environment with respect to the aforementioned dimensions in order to facilitate such an integration.

Yet, as was highlighted also by Rodrik (2018), it is important to consider the issue of GVCs with caution since the latter are intensive in new technologies that 
may present a double threat to low-income countries: First, the GVCs are generally biased towards skills that reduce the comparative advantage of developing countries that are endowed with unskilled labor and specialized in traditionally labor-intensive manufacturing activities. Second, GVCs make it harder for these countries to use their labor-cost advantage, by reducing their ability to substitute unskilled labor for other production inputs.

Acknowledgements This work was supported by French National Research Agency Grants ANR-17EURE-0020 and a research Grant financed by the Economic Research Forum (Cairo, Egypt). We are grateful to Bernard Hoekman (European University Institute) and David C. Francis (World Bank) for their constructive comments.

\section{Appendix 1: List of Countries and Years of the WBES}

\begin{tabular}{|c|c|c|}
\hline Afghanistan $(2008,2014)$ & Gambia, The (2006) & Nicaragua $(2006,2010,2016)$ \\
\hline Angola $(2006,2010)$ & Ghana $(2007,2013)$ & Niger $(2009,2017)$ \\
\hline Argentina $(2006,2010)$ & Guatemala $(2006,2010)$ & Nigeria $(2007,2014)$ \\
\hline Bangladesh $(2007,2013)$ & Guinea $(2006,2016)$ & Pakistan $(2007,2013)$ \\
\hline Belize (2010) & Guinea-Bissau (2006) & Panama $(2006,2010)$ \\
\hline Benin $(2009,2016)$ & Honduras $(2006,2010)$ & Paraguay $(2006,2010,2017)$ \\
\hline Bhutan $(2009,2015)$ & India (2014) & Peru $(2006,2010)$ \\
\hline Bolivia $(2006,2010,2017)$ & Indonesia $(2009,2015)$ & Philippines $(2009,2015)$ \\
\hline Botswana $(2006,2010)$ & Jamaica (2010) & Rwanda $(2006,2011)$ \\
\hline Brazil (2009) & Jordan (2013) & Senegal $(2007,2014)$ \\
\hline Burkina Faso (2009) & Kenya $(2007,2013)$ & South Africa (2007) \\
\hline Burundi $(2006,2014)$ & Lao PDR $(2009,2012,2016)$ & Sri Lanka (2011) \\
\hline Cambodia $(2013,2016)$ & Lebanon (2013) & Sudan (2014) \\
\hline Cameroon $(2009,2016)$ & Lesotho $(2009,2016)$ & Suriname (2010) \\
\hline Central African Republic (2011) & Madagascar $(2009,2013)$ & Swaziland $(2006,2016)$ \\
\hline Chad (2009) & Malawi $(2009,2014)$ & Tanzania $(2006,2013)$ \\
\hline Chile $(2006,2010)$ & Malaysia (2015) & Thailand (2016) \\
\hline China (2012) & Mali $(2007,2010,2016)$ & Togo $(2009,2016)$ \\
\hline Colombia $(2006,2010)$ & Mauritania $(2006,2014)$ & Trinidad and Tobago (2010) \\
\hline Congo, Dem. Rep. (2006, 2010, 2013) & Mauritius (2009) & Tunisia (2013) \\
\hline Costa Rica (2010) & Mexico $(2006,2010)$ & Uganda $(2006,2013)$ \\
\hline Cote d'Ivoire $(2009,2016)$ & Mongolia $(2009,2013)$ & Uruguay $(2006,2010)$ \\
\hline Dominican Republic $(2010,2016)$ & Morocco (2013) & Vietnam $(2009,2015)$ \\
\hline Ecuador $(2006,2010)$ & Mozambique (2007) & Zambia $(2007,2013)$ \\
\hline Egypt, Arab Rep. $(2013,2016)$ & Myanmar $(2014,2016)$ & Zimbabwe $(2011,2016)$ \\
\hline El Salvador $(2006,2010,2016)$ & Namibia $(2006,2014)$ & \\
\hline Eritrea (2009) & Nepal $(2009,2013)$ & \\
\hline
\end{tabular}

Source: Constructed by the authors using the WBES 


\section{Appendix 2: Variable Definitions and Sources}

\begin{tabular}{|c|c|c|c|}
\hline Dimension & Label & Definition & Source \\
\hline \multicolumn{4}{|c|}{ Infrastructure } \\
\hline Factual & Generator & $\begin{array}{l}\text { Percentage of firms declaring having a generator by country, } \\
\text { industry, region, and year }\end{array}$ & WBES \\
\hline $\begin{array}{l}\text { Doing bus. } \\
\text { Finance }\end{array}$ & Proc. obtaining elec. & Obtaining electrical service—procedures (number) (log) & DB \\
\hline Factual & Self finan. & Whether the firm is self-financing its investments & WBES \\
\hline Factual & Bank finan. & Whether the firm is financing its investments through banks & WBES \\
\hline $\begin{array}{l}\text { Doing bus. } \\
\text { Fiscal }\end{array}$ & Credit regis. cov & Getting credit—credit registry coverage ( $\%$ of adults). & DB \\
\hline Doing bus. & Number of pay. & Paying taxes-payments (number per year-log) & DB \\
\hline $\begin{array}{l}\text { Doing bus. } \\
\text { Enforcing }\end{array}$ & Time to pay tax & Paying taxes - time (hours per year) (log) & DB \\
\hline Doing bus. & Proc. enf. contracts & Enforcing contracts-procedures (number) (log) & DB \\
\hline $\begin{array}{l}\text { Doing bus. } \\
\text { Permits }\end{array}$ & Time res. insolvency & Resolving insolvency-time (years) (log) & DB \\
\hline Doing bus. & Proc start bus. & Starting a business-procedures-men (number, $\log$ ). & DB \\
\hline $\begin{array}{l}\text { Doing bus. } \\
\text { Informality }\end{array}$ & Proc regis prop. & Registering property-procedures (number, log). & DB \\
\hline Factual & Informality & $\begin{array}{l}\text { Average } \% \text { of firms competing against informal firms by } \\
\text { country, industry, region and year }\end{array}$ & WBES \\
\hline Factual & Sales inf. pay. & $\begin{array}{l}\text { Average } \% \text { of total sales paid in informal payments by coun- } \\
\text { try, industry, region and year }\end{array}$ & WBES \\
\hline \multicolumn{4}{|c|}{ Trade procedures } \\
\hline Perception & Trade obs. & $\begin{array}{l}\text { Average } \% \text { of firms declaring customs and trade regulations } \\
\text { as a major or a severe obstacle }\end{array}$ & WBES \\
\hline Doing bus. & Doc to exp. & $\begin{array}{l}\text { Trading across borders-documents to export (number) } \\
(\log )\end{array}$ & DB \\
\hline Doing bus. & Doc to imp. & $\begin{array}{l}\text { Trading across borders-documents to import (number) } \\
(\log )\end{array}$ & DB \\
\hline Doing bus. & Time to exp. & Trading across borders-time to export (days) (log) & DB \\
\hline $\begin{array}{l}\text { Doing bus. } \\
\text { Security }\end{array}$ & Time to imp. & Trading across borders-time to import (days) (log) & DB \\
\hline Factual & Break & $\begin{array}{l}\text { Average } \% \text { of value of products lost in transit due to break- } \\
\text { age or spoilage by country, industry, region and year }\end{array}$ & WBES \\
\hline Doing bus. & Protec inv. (Liab.) & $\begin{array}{l}\text { Protecting minority investors-extent of director liability } \\
\text { index }(0-10)\end{array}$ & DB \\
\hline
\end{tabular}

\section{References}

Augier, P., Dovis, M., \& Gasiorek, M. (2012). The business environment and Moroccan firm productivity. Economics of Transition, 20(2), 369-399. 
Bah, E., \& Fang, L. (2015). Impact of the business environment on output and productivity in Africa. Journal of Development Economics, 114, 159-171.

Baldwin, R. (2013). Global supply chains: Why they emerged, why they matter, and where they are going. In D. K. Elms \& P. Low (Eds.), Global value chains in a changing world (Vol. 1, pp. 13-59). Geneva: World Trade Organization (WTO).

Baldwin, J., \& Yan, B. (2014). Global value chains and the productivity of Canadian manufacturing firms. In Economic analysis research paper series. Statistics Canada, Ottawa.

Berman, N., \& Héricourt, J. (2010). Financial factors and the margins of trade: Evidence from crosscountry firm-level data. Journal of Development Economics, 93, 206-217.

Bernard, A. B., Eaton, J., Jensen, J. B., \& Kortum, S. (2003). Plants and productivity in international trade. American Economic Review, 93, 1268-9121.

Bernard, A. B., \& Jensen, J. B. (2004). Why some firms export. The Review of Economics and Statistics, 86(2), 561-569.

Brambilla, I., Lederman, D., \& Porto, G. (2012). Exports, export destinations, and skills. American Economic Review, 102, 3406-3438.

Commander, S., \& Svejnar, J. (2011). Business environment, exports, ownership, and firm performance. The Review of Economics and Statistics, 93(1), 309-337.

Dai, M., Maitre, M., \& Yu, M. (2016). Unexceptional exporter performance in China? The role of processing trade. Journal of Development Economics, 121, 177-189.

De Hoyos, R., \& Iacovone, L. (2013). Economic performance under NAFTA: A firm-level analysis of the trade-productivity linkages. World Development, 44, 180-193.

Del Prete, D., Giovannetti, G., \& Marvasi, E. (2017). Global value chains participation and productivity gains for North African firms. Review of world Economics, 153(4), 675-701.

Dollar, D., Hallward-Driemeier, M., \& Mengistae, T. A. (2005). Investment climate and firm performance in developing countries. Economic Development and Cultural Change, 54(1), 1-31.

Eaton, J., Kortum, S., \& Kramarz, F. (2004). Dissecting trade: Firms, industries, and export destinations. American Economic Review, 94, 150-154.

El-Said, H., Al Said, M., \& Zaki, C. (2015). Trade and access to finance of SMEs in Egypt: Is there a nexus? Applied Economics, 47(39), 4184-4199.

Ethier, W. (1982). National and international returns to scale in the model theory of international trade. American Economic Review, 72(3), 389-405.

Feng, L., Li, Z., \& Swenson, D. (2016). The connection between imported intermediate inputs and exports: Evidence from Chinese firms. Journal of International Economics, 101, 86-101.

Fernandes, A. M. (2008). Firm productivity in Bangladesh manufacturing industry. World Development, 36(10), 1725-1744.

Foster-McGregor, N., Kaulich, F., \& Stehrer, R. (2015). Global value chains in Africa. No 2015-024, MERIT Working Papers, United Nations University - Maastricht Economic and Social Research Institute on Innovation and Technology (MERIT).

Freund, C., \& Pierola, M. D. (2015). Export superstars. Review of Economics and Statistics, 97(5), 1023-1032.

Frias, J., Kaplan, D., \& Verhoogen, E. (2012). Exports and wage premia: Evidence from mexican employer-employee data. American Economic Review Papers and Proceedings, 102, 435-440.

Goedhuys, M., Janz, N., \& Mohnen, P. (2010). What drives productivity in Tanzania manufacturing firms: Technology or business environment? The European Journal of Development Research, 20(2), 199-218.

Grossman, G., \& Helpman, E. (1991). Innovation and growth in the global economy. Cambridge, MA: MIT Press.

Hallward-Driemeier, M., Wallsten, S., \& Xu, L. C. (2006). Ownership, investment climate and firm performance: Evidence from Chinese firms. Economics of Transition, 14(4), 629-647.

Hulten, C. R., Bennathan, E., \& Srinivasan, S. (2006). Infrastructure, externalities, and economic development: A study of the Indian manufacturing industry. The World Bank Economic Review, 20(2), 291-308.

Jaud, M., \& Freund, C. (2015). Champions wanted-Promoting exports in the Middle East and North Africa. Washington, DC: World Bank.

Ju, J., \& Yu, X. (2015). Productivity, profitability, production and export structures along the value chain in China. Journal of Comparative Economics, 43, 33-54.

Kasahara, H., \& Lapham, H. (2013). Productivity and the decision to import and export; theory and evidence. Journal of International Economics, 89, 297-316. 
Kasahara, H., \& Rodrigue, J. (2008). Does the use of imported intermediates increase productivity? Plant-level evidence. Journal of Development Economics, 87, 106-118.

Lu, J., Lu, Y., \& Tao, Z. (2010). Export behavior of foreign affiliates: Theory and evidence. Journal of International Economics, 81, 197-205.

Manova, K., \& Yu, Z. (2016). How firms export: Processing vs. ordinary trade with financial frictions. Journal of International Economics, 100, 120-137.

Markusen, J. R. (1989). Trade in producer services and in other specialized intermediate inputs. American Economic Review, 79(1), 85-95.

Melitz, M. (2003). The impact of trade on intra-industry reallocations and aggregate industry productivity. Econometrica, 71, 1695-1725.

Muûls, M., \& Pisu, M. (2009). Imports and exports at the level of the firm: Evidence from Belgium. The World Economy, 32(5), 692-734.

Rodrik, D. (2018). New technologies, global value chains, and the developing economies. Background paper no. 1, pathways for prosperity commission background paper series; no. 1. Oxford, UK.

Schmidt, K. M. (1997). Managerial incentives and product market competition. Review of Economic Studies, 64, 191-213.

Smeets, V., \& Warzynski, F. (2013). Estimating productivity with multi-product firms, pricing heterogeneity and the role of international trade. Journal of International Economics, 90, 237-244.

UNCTAD. (2013). Trade and development report. New York and Geneva: United Nations.

Van Biesebroeck, J. (2005). Firm size matters: Growth and productivity growth in African manufacturing. Economic Development and Cultural Change, 53(3), 545-583.

World Bank. (2017). Doing business. Washington, DC: World Bank.

Yeaple, S. R. (2005). A simple model of firm heterogeneity, international trade, and wages. Journal of International Economics, 65, 1-20.

$\mathrm{Yu}$, M. (2015). Processing trade, tariff reductions and firm productivity: Evidence from Chinese firms. The Economic Journal, 125, 943-988. 